\title{
Phosphorus Non-Point Pollution from Equestrian Wastes and the Need for Recycling
}

\author{
J. William Louda ${ }^{1}$, Bobby G. Duersch ${ }^{1}$, Jeffrey T. Osetek ${ }^{1,2}$, Charmaine Cintron ${ }^{1,3}$, Lorraine Chaljub ${ }^{1,4} \&$ Vittoria \\ Queiroz $^{1}$ \\ ${ }^{1}$ Department of Chemistry and Biochemistry, Florida Atlantic University, Boca Raton, Florida 33431, USA \\ ${ }^{2}$ Suncor Energy, Commerce City, Colorado 80022, USA \\ ${ }^{3}$ Biometric Identification Unit, Broward County Sherriff's Office, Ft. Lauderdale, Florida 33312, USA \\ ${ }^{4}$ Teva Pharmaceuticals-Florida Site, Davie, Florida 33331, USA \\ Correspondence: J. William Louda, Department of Chemistry and Biochemistry, Florida Atlantic University, Boca \\ Raton, Florida 33431, USA. Tel: 1-561-797-1852. E-mail: blouda@fau.edu
}

Received: May 10, $2021 \quad$ Accepted: June 18, $2021 \quad$ Online Published: July 7, 2021

doi:10.5539/ep.v10n2p61 URL: https://doi.org/10.5539/ep.v10n2p61

\begin{abstract}
South Florida and much of the rest of the World suffers from harmful algal blooms (HABs) and controls of both nitrogen $(\mathrm{N})$ and phosphorus $(\mathrm{P})$ pollution are required to curtail the onset, spread and/or expansion of these blooms.

This report covers our studies on several aspects of equestrian waste (viz. horse manure) aimed at yielding an overview of phosphorus and its pollution stemming from non-point horse manure sources in portions of Palm Beach County Florida. Methods included a modified Hedley extraction sequence, emphasizing 'easily extractable phosphorus' (EEP), and ${ }^{31} \mathrm{P}$ nuclear magnetic resonance (NMR) spectroscopic identification of organic phosphorus $\left(\mathrm{P}_{\mathrm{o}}\right)$ species.

Samples included fresh and aged horse manure, pasture soils, horse feed and pasture grasses, and canal waters adjacent to equestrian or agricultural fields.

Easily extractable Phosphorus (EEP) averaged about $54-77 \%$ of the total horse manure phosphorus. Total phosphorus ranged from $13,020-22,300 \mathrm{mg}$ per kilogram dry weight. $\left(\approx 60-100 \mathrm{lbs} . \mathrm{P}_{2} \mathrm{O}_{5} /\right.$ ton and on a wet weight basis, this equates to 4,000 to 14,818 grams-P/ U.S. ton or 8.8 to 32.6 pounds of phosphorus $(\approx 20-75 \mathrm{lb}$. $\mathrm{P}_{2} \mathrm{O}_{5}$ ) per wet weight ton of horse manure. Considering the values of EEP in fresh samples from a single horse, we found a range of $8,000-17,000 \mathrm{mg}-\mathrm{P} / \mathrm{kg}(8-17 \mathrm{~g}-\mathrm{P} / \mathrm{kg})$ dry weight horse manure.
\end{abstract}

Soil samples yielded the highest $\mathrm{P}$ in the $\mathrm{NaOH}$ extract of the Hedley sequence. This equates to the $\mathrm{Al}, \mathrm{Fe}$ and ester forms.

Phosphorus (viz. EEP) runoff is viewed here as a non-point $\mathrm{P}$ pollution source.

Keywords: algal blooms, equestrian activities, horse manure, phosphorus, pollution, recycling

\section{Introduction}

The pollution of surface waters with primary plant nutrients, notably nitrogen and phosphorus, is increasing worldwide (Carpenter et al., 1998; Elser et al., 2007; Guignard et al., 2017; Smith et al., 1999). Nutrients can be and often are addressed within watershed management programs through processes termed best management practices (BMPs: FDACS, 2011; FDEP, 2013; Gunsalus et al., 1992; Mullins et al., 2005; Sims et al., 2000; USEPA, 2005) or decision support tools (DST: Drohan et al., 2019). It is noted that lag-times between implementation of BMPs and detection of impacts can range from years to decades (Meals et al., 2010).

In the October 2016 United States Environmental Protection Agency report entitled "National Nonpoint Source Program", it was stated "Of all the waterbodies across the nation that have been assessed and a possible source of impairment identified, $85 \%$ of rivers and streams and $80 \%$ of lakes and reservoirs are polluted by nonpoint sources." (USEPA, 2016).

Under the United States Clean Water Act Section 502, General Definitions, it states: “The term 'point source' means any discernible, confined and discrete conveyance, including but not limited to any pipe, ditch, channel, 
tunnel, conduit, well, discrete fissure, container, rolling stock, concentrated animal feeding operation, or vessel or other floating craft, from which pollutants are or may be discharged. This term does not include agricultural stormwater discharges and return flows from irrigated agriculture." (USEPA, 2019).

It is the last sentence in the above definition that generates the idea of 'non-point' sources (NPS) from agricultural operations. That is, "Nonpoint source pollution on the other hand comes from dispersing overland flow associated with rain events." (Pierce et al., 1998). Nonpoint nitrogen and phosphorus pollution is a well-known worldwide problem (Carpenter et al., 1998; Lankoski and Ollikainen, 2013; Xia et al., 2020).

Pollution due to the leaching of manure derived nitrogen and phosphorus is well known (e.g. Carpenter, 2008; Hart and Cornish, 2012; Horta and Torrent, 2007; Liu et al., 2018; McDowel et al., 2020; Vadas et al., 2007). Many process-based mathematical models exist and utilize input data including nutrient concentrations, water flow, soil types, weather and numerous other parameters in order to develop and/or characterize BMP efficiencies. Such programs include SWAT (Soil and Water Assessment Tool) developed by the United States Department of Agriculture (Arnold et al., 1998; Neitsch et al., 2011; Shen et al., 2015). Several other models also exist (see e.g. Liu et al., 2019; Tuo et al., 2015) for the assessment of basin and catchment scale studies.

South Florida has been and still is experiencing nutrient (N, P) excesses in surface waters and sediments in Lake Okeechobee (Fisher et al., 2005; Havens, 1995; Havens and East, 1997; Havens and Thomas, 2005; Pollman and Thomas, 2011;), coastal estuaries (Duersch and Louda, 2017; Liu et al., 2009; Pant and Reddy, 2001; Phlips et al., 2002 ) and the Greater Everglades (Bruland et al., 2007; Childers et al., 2003; Coralles et al., 2014; Louda et al.,2015; Reddy et al., 2011). Sources include sewerage, notably septic systems (aka OSTDS, Onsite Sewerage Treatment and Disposal Systems: Badruzzaman et al., 2012; FDOH, 2013; Lapointe et al., 2017; Meeroff et al., 2014), agricultural operations (Boggess et al., 1997; Duersch et al., 2020; Entry and Gottlieb, 2014; Stuck et al., 2001) and a growing equestrian industry (Cintron and Louda, 2007; Louda et al., 2019; Osetek and Louda, 2004).

Equestrian waste, notably manure, has received considerable attention pertaining to its use as agricultural fertilizer (e.g. Antonious et al., 2019; Flores et al., 2007; Motavalli and Miles, 2002; Shtangeeva et al., 2004; Tadesse et al., 2020; Zhu et al., 2012). Horse manure has also been studied for its role in N and P pollution (Cintron and Louda, 2007; Edwards et al., 1999; Liu et al., 2018; Louda et al., 2019; Paglari et al., 2012; Parvage et al., 2013; Narvanen et al., 2008).

The growth of the equestrian industry in south Florida, reaching 17-20,000 horses just in and around the Village of Wellington in Palm Beach County (Fig. 1), has been discussed frequently in local news media (e.g. Capone, 2019; Webb, 2019) and environmental news (FlaSpec, 2017). It is reported that about 500,000 horses, including 134,000 racing industry and 207,000 thoroughbreds, are in Florida year round (HorsePropNet, 2020). Much of the seasonal (Fall-Winter) horse population in Palm Beach County is involved in several Wellington horse shows including; the Wellington Horse Show, the Winter Equestrian Festival, Olympic level competitions, the Adequan Global Dressage Festival, and several Grand Prix events (WER, 2020). A single horse produces about 50 pounds of manure / waste per day, equating to over 9 tons per year (FDACS, 2011; FDEP, 2013; Krogman et al., 2006) Not including urine and manure contaminated bedding material wastes, it is reported that over 180-200,000 tons of horse manure is generated in Palm Beach County each year (FlaSpec, 2017).

Phytate (aka Phytic Acid, inositol hexakisphosphate (IUPAC nomenclature is $1 R, 2 S, 3 r, 4 R, 5 S, 6 s$-cyclohexane1,2,3,4,5,6-hexayl hexakis-dihydrogen phosphate) is the major storage form of phosphorus in plants (Cosgrove, 1980; Skoglund et al., 2009; Xie et al., 2020) and is generally not digested by non-ruminant animals lacking the enzyme phytase (Dersjant-Li et al., 2015). As ruminants, horses are highly capable of releasing phosphate from phytate with efficiencies reported at 93-95\% (Fowler et al., 2015; Lavin et al., 2013) due to phytase activity mainly in the lower large intestine (Matsui et al., 1999).

The current report covers several investigations aimed at providing an overview of phosphorus pollution stemming from non-point horse manure sources in portions of Palm Beach County Florida. Interest in this problem arose after hearing about and viewing the extreme overuse of horse manure and urine/manure soaked bedding on the nurseries and sugar cane fields in Palm Beach County. Agricultural landowners that receive equestrian waste (manure and bedding) receive "tipping fees" from the waste haulers. Therefore, the financial advantage of taking more than is needed appears drive this abuse.

Controls of both nitrogen $(\mathrm{N})$ and phosphorus $(\mathrm{P})$ pollution are required to curtail the onset, spread and/or expansion of micro- / macro- algal and cyanobacterial blooms (Paerl 1988, Paerl 2008, Paerl et al. 2011, Gobler et al. 2016; Paerl et al., 2016, Jankowiak et al., 2019, Levy 2017, Lu et al. 2019). Alterations of the watershed $\mathrm{C}: \mathrm{N}: \mathrm{P}$ values, the Redfield ratio (Redfield, 1934, 1958), are known to occur from agriculture field runoff (Smith et al., 2019). 
We analyzed fresh and aged manure, various horse feed materials, surface and sub-surface soils, and canals that received surface / subsurface runoff of agricultural fields.

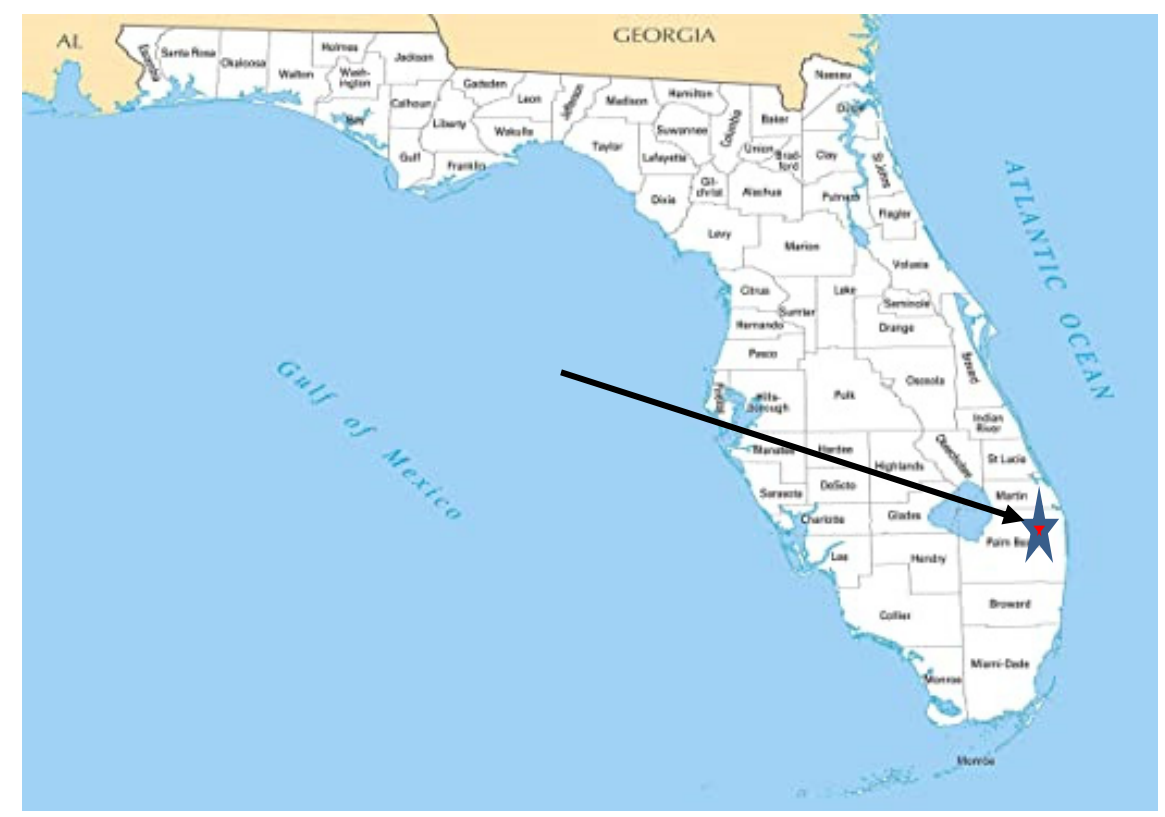

Figure 1. Map of Florida counties with the location of the Village of Wellington and the Town of Loxahatchee Groves indicated by the arrow pointing to a star

Emphasis was placed on the 'easily extractable phosphorus' (EEP) which consists of the phosphorus that is extracted with water and mild $\left(0.1 \mathrm{M}\right.$ sodium bicarbonate, $\left.\mathrm{NaHCO}_{3}\right)$. This is also termed "Olsen P" (Olsen et al., 1954; Horta and Torrent, 2007; McDowell et al., 2020) or "soil-test phosphorus" (Hart and Cornish, 2012). Water extractable phosphorus (WEP) is often taken to mimic dissolved reactive phosphorus (DRP) in soil surface runoff (McDowell et al., 2020). WEP is the main part of the EEP and forms the first extract of the well-known Hedley fractionation scheme (Dou et al., 2000; Hedley et al., 1982).

Though phosphorus accretion from equestrian activities is but one part of the larger overall $\mathrm{P}$ and $\mathrm{N}$ surface water pollution problem, identifying areas where recycling can enter and enhance BMPs should contribute significantly to environmental remediation efforts.

\section{Materials and Methodologies}

\section{1 - Materials}

Horse manure was collected from fields and roads within the Town of Loxahatchee Groves and the Village of Wellington Florida by hand using inverted 1-gallon Ziploc ${ }^{\circledR}$ bags. In addition to horse manure, soil, and water analyses, we also examined selected samples of horse feed. This included pasture grasses, Timothy and Alfalfa (T\&A), and Purina Pride $100^{\circledR}$ and Nutrena Proforce Senior ${ }^{\mathbb{B} .}$ horse chows.

Surface soil samples were made using a stainless steel scoop and the samples placed into sealed sample jars (e.g. wide mouth HDPE, Thermo Scientific ${ }^{\mathrm{TM}}$ \#3110500). Soil samples for depth studies were collected using a WILDCO $^{\circledR}$ hand-driven core sediment sampler (WILDCO \#77258) with a stainless steel nosepiece. Cores were kept at ice / refrigerator temperatures $\left(\sim 4^{\circ} \mathrm{C}\right)$ until sectioning and extractions were undertaken. The soil core was extruded from the core liner and sectioned into $1.2 \mathrm{~cm}$ sample layers.

Water samples were collected from bridges with a WILDCO 1120-G40 horizontal alpha water sampler of 2.2 L capacity. Water samples from canal or lake banks were collected using a 1.0-Liter rectangular amber HDPE bottle attached to an aluminum pole using a Castaloy ${ }^{\mathrm{TM}}$ chain clamp. In both cases, water was then transferred to wellrinsed amber HDPE rectangular bottles and, as with manure and soil samples, placed on ice, if not being analyzed within 2-3 hours, and transported to the lab for analyses.

\subsection{Methodologies}

\subsubsection{Phosphate - limestone study}

The limestone related removal of phosphates from natural canal waters or manure extracts in HPLC grade water 
was examined by mixing with either fine grained (Fisher Scientific C64-500) or solid chunk (ACROS $\mathrm{AC} 403790020$ ) calcium carbonate (aka calcite; $\mathrm{CaCO}_{3}$ ) added.

\subsubsection{Phosphorus extractions and quantitation}

The modified Hedley fractionation scheme (ex. Dou et al., 2000; cf. Hedley et al., 1982) for the extraction of phosphate from various phosphorus forms is given as Table 1. Water alone extracts free soluble reactive phosphorus (SRP) also commonly termed ortho-phosphate $\left(\mathrm{PO}_{4}{ }^{3+}\right)$ or water extractable phosphorus (WEP), as described in the Introduction. Mild aqueous bicarbonate releases SRP from easily labile phosphates, notably pyrophosphate and polyphosphates. The sodium hydroxide solution releases SRP from amorphous-crystalline Al and Fe phosphates as well as phosphorus mono- and di-esters. The hydrochloric acid extraction frees SRP from $\mathrm{Ca}$ and $\mathrm{Mg}$ bound states. Lastly, digestion with strong acids releases SRP from organic phosphates. Each extraction includes 16 hours shaking.

Table 1. Modified Hedley fractionation scheme (Dou et al., 2000; Hedley et al., 1982)

\begin{tabular}{cc}
\hline Extractant & Phosphorus type(s) \\
\hline water & Soluble Reactive Phosphorus (SRP) \\
$0.5 \mathrm{M} \mathrm{NaHCO} 3 \mathrm{pH}=8.5$ & Easily labile phosphates \\
$0.1 \mathrm{M} \mathrm{NaOH}$ & Al- \& Fe- and mono- / di-ester phosphates \\
$1 \mathrm{M} \mathrm{HCl}$ & Stable Ca \& Mg bound phosphates \\
$60 \% \mathrm{HClO} 4: \mathrm{H} 2 \mathrm{SO} 4,2: 1, \mathrm{v} / \mathrm{v}$ & Organic phosphates (Po)
\end{tabular}

$\mathrm{EEP}=$ Easily Extractable Phosphorus $=$ sum of water and mild bicarbonate extracts.

Ortho-phosphate, also known as soluble reactive phosphorus (SRP), present in and/or released from each fraction was measured by the molybdenum blue method. Reactive phosphorus (SRP) analyses were performed using HACH Chemical company reagent sets as follows: TNT \#2742545 (0.06-5.00 $\left.\mathrm{mg} \mathrm{PO}_{4}{ }^{3-} \mathrm{L}^{-1}\right)$, TNT-Plus \# $843(0.15$ - $4.5 \mathrm{mg} \mathrm{PO}{ }_{4}^{3-} \mathrm{L}^{-1}$ ) and TNT-Plus \#844 (1.5 - $\left.15.0 \mathrm{mg} \mathrm{PO}_{4}{ }^{3-} \mathrm{L}^{-1}\right)$. Total phosphorus (TP) analyses were made with HACH Chemical company reagent sets as follows: TNT \#2742645 (0.06-3.50 $\left.\mathrm{mg} \mathrm{PO}_{4}{ }^{3-} \mathrm{L}^{-1}\right)$, TNT-Plus \# $843(0.15$ - $\left.4.5 \mathrm{mg} \mathrm{PO}{ }^{3-} \mathrm{L}^{-1}\right)$ and TNT-Plus $\# 844\left(1.5-15.0 \mathrm{mg} \mathrm{PO}_{4}{ }^{3-} \mathrm{L}^{-1}\right)$. Phosphate data was multiplied by 0.3621 to convert to phosphorus (P) values or read directly as such. Total phosphate (TP) digestions were performed using HACH DRB200 reactors.

Spectrophotometric measurements were made using HACH DR5000 and DR3900 spectrophotometers by the molybdenum blue methods given above. Zero concentration was determined by testing HACH deionized water with each method and subtracting the method background from the observed reading during each analysis.

In all cases, standardization versus NIST-traceable standards gave $\mathrm{y} \approx 1 \mathrm{x}$ with $\mathrm{R}^{2} \approx 1.00$. That is: DR5000 $(\mathrm{y}=$ $\left.1.0713 \mathrm{x}, \mathrm{R}^{2}=0.9931\right)$; DR3900 $\left(\mathrm{y}=0.9539 \mathrm{x}, \mathrm{R}^{2}=0.9997\right)$. The NIST traceable phosphate standards were $(\mathrm{HACH}$ \#27428) from 1mg/L (HACH \#256949), 15mg/L (HACH \# 1424342), and a mixed-parameter standard with phosphate-P at a level of $1.0 \mathrm{mg} / \mathrm{L}(\mathrm{SRP}=3.066 \mathrm{mg} / \mathrm{L}: \mathrm{HACH}$ \# LCA721). These standards were then diluted using HACH deionized water (\#27248).

Total phosphorus was also determined in certain samples by Inductively-Coupled Plasma Mass Spectrometry (ICP-MS). ICP-MS analyses were contracted to the Florida Atlantic University Water Analysis Laboratory FAUWAL) located in Davie, Florida (Dr. T. Root, director).

\subsubsection{Organic phosphorus characterization}

Sequential fractionation methods, such as the Hedley fractionation discussed above, measure P pools centered on the solubility of extractants and do not determine specific inorganic or organic P compounds (Negassa and Leinweber, 2009; Condron and Newman, 2011). Therefore, in order to assess the organic phosphorus species in horse manure, we incorporated ${ }^{31} \mathrm{P}$ Nuclear Magnetic Resonance spectroscopy $\left({ }^{31} \mathrm{P}-\mathrm{NMR}\right)$. A $400 \mathrm{MHz}$ Brüker NMR with a phosphorus probe was used to analyze whole samples (see Duersch, 2020). Samples were frozen in liquid nitrogen and subsequently lyophilized. Freeze-dried samples were reconstituted in $400 \mu \mathrm{L} \mathrm{D}_{2} \mathrm{O}, 400 \mu \mathrm{L} 0.05$ M EDTA / $0.25 \mathrm{M} \mathrm{NaOH}$ solution, and $200 \mu \mathrm{L} 1.0 \mathrm{M} \mathrm{NaOH}$ to ensure $\mathrm{pH}$ above 12 in accord with Cade-Menun (2015). The solutions were agitated for one minute and then centrifuged at 4,000 x g for $5 \mathrm{~min}$. The solution was then placed in a $5 \mathrm{~mm}$ NMR tube and immediately analyzed. The NMR instrumental parameters were set as follows: 
frequency at $161.98 \mathrm{MHz} ; \mathrm{T}_{1}$ relaxation delay time at $5 \mathrm{sec}$.; pulse angle $90^{\circ}$; acquisition time at $1.0 \mathrm{sec}$. Data were analyzed using TopSpin 3.6.2 ${ }^{\circledR}$ software. P compounds were identified by their chemical shifts (ppm) relative to the orthophosphate peak set to $6.00 \mathrm{ppm}$.

\section{Results and Discussion}

\subsection{Results}

\subsubsection{Phosphorus in Horse Manure}

A wide variety of horse manure, fresh and aged, was tested over the course of these studies. Here we present representative results for the Hedley fractionation of phosphorus types in various different manure samples. "Fresh" manure is defined here as that was excreted within 6-12 hours of collection. "Aged" manure (CC\#2 Aged) was in the field for several days to weeks. It should be noted that the aged samples were collected during the dry season. That is, only small amounts of rain occurred during that period.

Sample CC\#1 was aged in vitro at room temperature from CC\#1-Fresh (Table 2) without the application of external water. In this case, Easily Extractable Phosphorus (EEP) was found to have decreased in percentage in concert with increases in the relative amount of $\mathrm{Al}$ and $\mathrm{Fe}$ bound $\mathrm{P}$ increasing by $58 \%$ (2.6 to $4.1 \mathrm{~g}-\mathrm{P} / \mathrm{kg})$.

The yields of Hedley phosphorus fractions (groups), both as phosphate and phosphorus in mg per gram dry weight of manure, are given in Table 2. This data is also presented graphically as Figure 2.

Table 2. Representative Hedley fractionation results for fresh and aged (several weeks) horse manure. "EEP" = Easily Extractable Phosphorus $=$ SRP plus labile forms

\begin{tabular}{|c|c|c|c|c|c|c|c|}
\hline \multirow[b]{2}{*}{ Sample } & \multirow[b]{2}{*}{ Extractant } & \multirow[b]{2}{*}{ Fraction } & \multicolumn{2}{|l|}{ Yield (dry wt.) } & \multicolumn{2}{|c|}{ Yield (wet wt.). } & \multirow{2}{*}{$\begin{array}{l}\text { Percent } \\
\text { "EEP" }\end{array}$} \\
\hline & & & $\mathrm{mg}-\mathrm{PO}_{4}{ }^{3-} / \mathrm{kg}$ & $\mathrm{mg}-\mathrm{P} / \mathrm{kg}$ & $\mathrm{mg}-\mathrm{P} / \mathrm{kg}$ & $\% \mathrm{P}$ & \\
\hline CC\#1 Fresh & $\mathrm{H}_{2} \mathrm{O}$ & SRP & 17,380 & 5,666 & 3,333 & 43.5 & 62.7 \\
\hline \multirow[t]{5}{*}{$57.1 \%$ wet wt } & $\mathrm{NaHCO}_{3}$ & labile-P & 7,660 & 2,497 & 1,469 & 19.2 & \\
\hline & $\mathrm{NaOH}$ & $\mathrm{Al} \& \mathrm{Fe} \& \mathrm{P}$-esters & 8,010 & 2,611 & 1,536 & 20.0 & \\
\hline & $\mathrm{HCl}$ & $\mathrm{Ca} \& \mathrm{Mg}$ bound-P & 1,010 & 329 & 194 & 2.5 & \\
\hline & Digestion & organic-P & 5,890 & 1,920 & 1,129 & 14.7 & \\
\hline & & TOTAL & 39,950 & 13,024 & 7,661 & & \\
\hline CC\#1 Aged & $\mathrm{H}_{2} \mathrm{O}$ & SRP & 16,240 & 5,294 & 2,052 & 36.4 & 54.2 \\
\hline \multirow[t]{5}{*}{$38.8 \%$ wet wt. } & $\mathrm{NaHCO}_{3}$ & labile-P & 7,940 & 2,588 & 1,003 & 17.8 & \\
\hline & $\mathrm{NaOH}$ & $\mathrm{Al} \& \mathrm{Fe} \& \mathrm{P}$-esters & 12,620 & 4,114 & 1,595 & 28.3 & \\
\hline & $\mathrm{HCl}$ & $\mathrm{Ca} \& \mathrm{Mg}$ bound-P & 970 & 316 & 123 & 2.2 & \\
\hline & Digestion & organic-P & 6,840 & 2,230 & 864 & 15.3 & \\
\hline & & TOTAL & 44,610 & 14,543 & 5,637 & & \\
\hline CC\#2 Aged & $\mathrm{H}_{2} \mathrm{O}$ & SRP & 23,380 & 7,622 & 2,066 & 46.9 & 72.3 \\
\hline \multirow[t]{5}{*}{$27.1 \%$ wet wt. } & $\mathrm{NaHCO}_{3}$ & labile-P & 12,660 & 4,127 & 1,118 & 25.4 & \\
\hline & $\mathrm{NaOH}$ & $\mathrm{Al} \& \mathrm{Fe} \& \mathrm{P}$-esters & 9,750 & 3,179 & 861 & 19.5 & \\
\hline & $\mathrm{HCl}$ & $\mathrm{Ca} \& \mathrm{Mg}$ bound-P & 870 & 284 & 77 & 1.7 & \\
\hline & Digestion & organic-P & 3,240 & 1,056 & 286 & 6.5 & \\
\hline & & TOTAL & 49,900 & 16,267 & 4,409 & & \\
\hline CC\#3 FRESH & $\mathrm{H}_{2} \mathrm{O}$ & SRP & 42,900 & 13,985 & 10,208 & 62.7 & 77.3 \\
\hline \multirow[t]{5}{*}{$73.0 \%$ wet wt. } & $\mathrm{NaHCO}_{3}$ & labile-P & 10,000 & 3,260 & 2,380 & 14.6 & \\
\hline & $\mathrm{NaOH}$ & $\mathrm{Al} \& \mathrm{Fe} \& \mathrm{P}$-esters & 11,900 & 3,879 & 2,832 & 17.4 & \\
\hline & $\mathrm{HCl}$ & $\mathrm{Ca} \& \mathrm{Mg}$ bound-P & 500 & 163 & 119 & 0.7 & \\
\hline & Digestion & organic-P & 3,100 & 1,011 & 738 & 4.5 & \\
\hline & & TOTAL & 68,400 & 22,298 & 16,276 & & \\
\hline
\end{tabular}




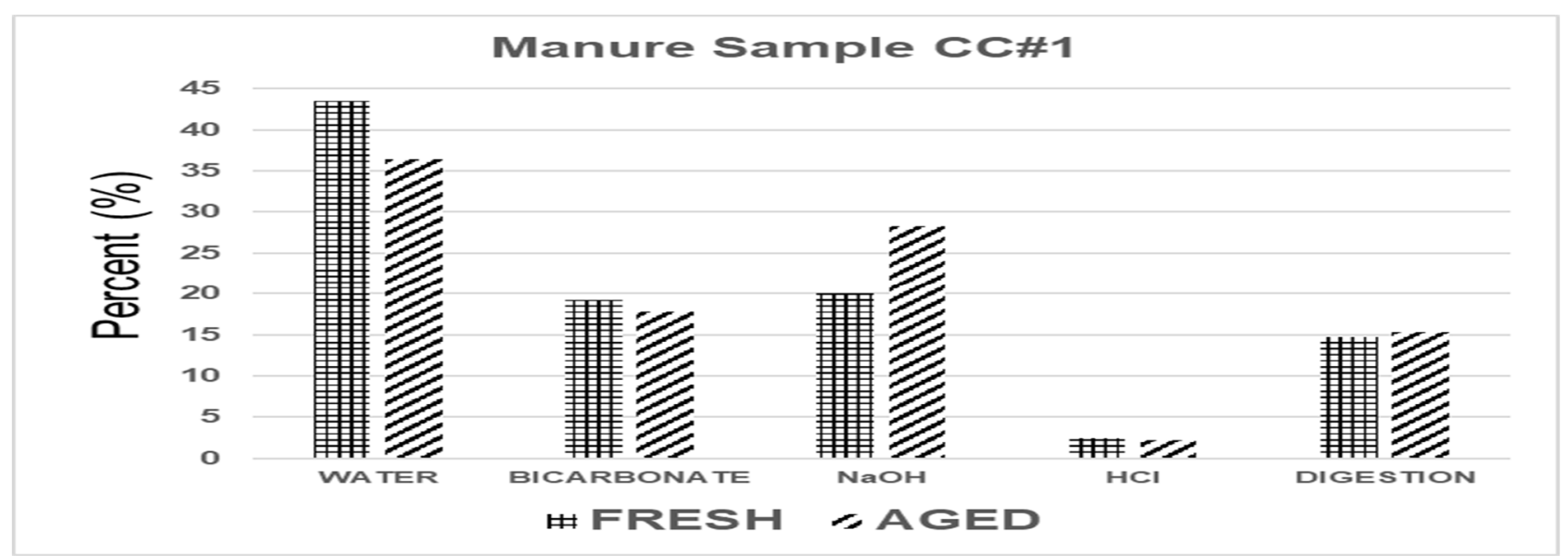

Figure 2. Graphic representation of phosphorus fractions in fresh and aged horse manure

\subsubsection{Variability Study of SRP Yields in Horse Manures}

All data presented above was arrived at by taking a large amount of the manure and mixing well (homogenizing) and then sub-sampling. For the variability test given here, we analyzed three separate sub-samples from each of three separate 'road apples' and in order to investigate the variability within fresh manure from a single animal deposited at the same time.

The samples varied in water weight from $59-82 \%$, equaling $41-18 \%$ dry weight. Here we centered on the EEP (Easily Extracted Phosphorus) by extracting with water and $0.5 \mathrm{M} \mathrm{NaHCO}_{3}$. Sample sizes were small $(0.5-1.7$ grams wet weight) in order to examine variability within the manure. The two larger fresh samples given above (Table 2) had quite variable EEP values of $8,163 \mathrm{mg} / \mathrm{kg}$-dry wt. (CC\#1-fresh) and 17,245 mg-P/kg-dry wt. (CC\#3fresh). The samples studied for within manure variability here (Table 3) had an overall mean value of 11,098 mg$\mathrm{P} / \mathrm{kg}$ dry wt. with a standard deviation of $1,392 \mathrm{mg}$-P/kg-dry wt. Across the samples from the three separate manure pieces (aka 'road apples'), the range of EEP (aka WEP, Olsen-P) was found to be 9,970 to 13,173 mg-P/kg ( 10$13 \mathrm{~g}-\mathrm{P} / \mathrm{kg}$ ) dry wt.

Considering the values of EEP for the fresh samples in Table 2 and the samples in the variability study, we can surmise a range of $8,000-17,000 \mathrm{mg}-\mathrm{P} / \mathrm{kg}(8-17 \mathrm{~g}-\mathrm{P} / \mathrm{kg})$ dry weight horse manure. Agricultural reports list 0.030.05 lb. $-\mathrm{P}_{2} \mathrm{O}_{5} / \mathrm{lb} .\left(\approx 60-100 \mathrm{lb}\right.$./ton) horse manure (e.g. NOLA, 2020; UMinn, 2020) and using $\mathrm{P}=44 \%$ of $\mathrm{P}_{2} \mathrm{O}_{5}$, that would equate to about $13-22 \mathrm{~g}-\mathrm{P} / \mathrm{kg}$-wet weight horse manure. Using an average percent water of $65 \%$, that would give 4.6-7.7 g-P/kg-dry weight.

Table 3. Water extracted, Hedley Fraction \#1, Soluble Reactive Phosphorus (SRP) in three separate fresh horse manure pieces ('road apples'). "a, b \& c" are sub-samples of samples \#1, 2 or 3

\begin{tabular}{lllllll}
\hline \multicolumn{7}{c}{ mg-P / kg manure } \\
\hline SAMPLE & WET & Mean & StdDev & DRY & Mean & StdDev \\
\hline RA-1a & 3,420 & 3,309 & 338 & 9,970 & 9,645 & 986 \\
RA-1b & 3,577 & & & 10,428 & & \\
RA-1c & 2,929 & & & 8,538 & & \\
& & & & & & \\
\hline RA-2a & 2,448 & 2,972 & 459 & 9,753 & 11,840 & 1,830 \\
RA-2b & 3,161 & & & 12,593 & & \\
RA-2c & 3,306 & & & 13,173 & & \\
& & & & & & \\
\hline RA-3a & 2,869 & 3,248 & 374 & 10,431 & 11,809 & 1,359 \\
RA-3b & 3,258 & & & 1,846 & & \\
RA-3c & 3,616 & & & & 13,149 & \\
\hline Overall means & 3,176 & 390 & & 11,098 & 1,392 \\
\hline
\end{tabular}




\subsubsection{Organic Phosphorus Forms in Horse Manure}

Characterizing the molecular speciation of individual $\mathrm{P}_{\mathrm{o}}$ compounds in natural environments is one of the more difficult analytical challenges in modern biogeochemistry (Ruttenberg, 2014; Schlesinger and Bernhardt, 2013; Sharp, 2002). The speciation and characterization through mass spectrometric techniques of samples with low concentrations of organic P, as well as those with complex backgrounds, has proven to be difficult (Masoom et al., 2013). ${ }^{31}$ P-NMR spectroscopy is a technique used to both identify and quantify complex P-containing molecules that have eluded other standard methods such as mass spectrometry and colorimetric techniques (Cade-Menun et al., 2006). $\mathrm{P}_{\mathrm{o}}$ within a sample is detected because the ${ }^{31} \mathrm{P}$ isotope is the only naturally occurring $\mathrm{P}$ isotope giving a $1 / 2$ spin. ${ }^{31} \mathrm{P}$ NMR is the optimal choice for the analysis of $\mathrm{P}_{\mathrm{o}}$ in environmental samples as it is a non-destructive technique and $\mathrm{P}$ yields a high gyromagnetic ratio $\left(\gamma=10.829 \mathrm{X} 10^{7} \mathrm{rad} / \mathrm{T} / \mathrm{sec}\right)$ with $100 \%$ natural abundance.

The peaks in the spectra of ${ }^{31} \mathrm{P}$ NMR analysis are represent the detected P-31 nuclei found in $\mathrm{P}_{\mathrm{o}}$ compounds. The spectra are generally acquired with ${ }^{1} \mathrm{H}$ decoupling, meaning that spin-spin couplings are not observed. ${ }^{31} \mathrm{P}$ spectra of various $\mathrm{P}_{\mathrm{o}}$ compound standards that have been ${ }^{1} \mathrm{H}{ }^{1} \mathrm{H}$ coupled are shown in Figure 3. Splitting of the peaks for a single $\mathrm{P}_{\mathrm{o}}$ compounds occurs due to the $J$-coupling caused by nearby $\mathrm{P}$ nuclei for an individual compound. An advantage of ${ }^{1} \mathrm{H}$ coupling is improved identification of $\mathrm{P}_{\mathrm{o}}$ species. However, it can slightly decrease the signal to noise as well as quantitative aspects (Cade-Menum, 2015; Cade-Menum and Liu, 2014). Chemical shifts of signals were determined in parts per million (ppm) relative to an external ortho-phosphoric acid standard.

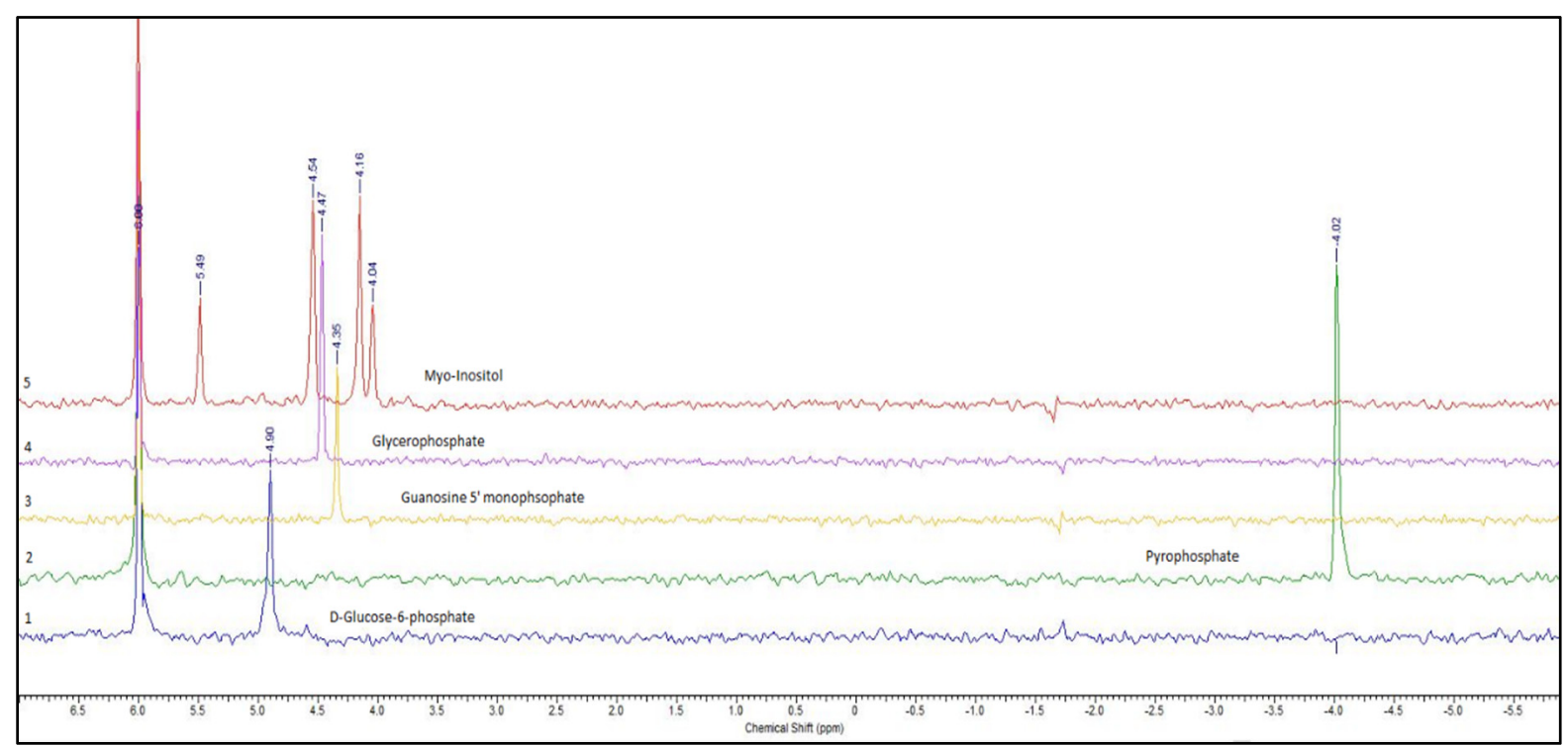

Figure 3. Proton decoupled ${ }^{31} \mathrm{P}$ NMR spectra of different $\mathrm{P}$ compound standards and their respective peak shifts. "Myo-inositol" = myo-inositol-hexakisphosphate (phytic acid). Orthophosphate was the reference at $6.00 \mathrm{ppm}$

Figure 4 is a ${ }^{1} \mathrm{H}$ decoupled ${ }^{31} \mathrm{P}$ NMR spectrum of the various phosphorus species in a fresh horse manure of the current study. The air-dried sample was extracted with an alkaline solution (NaOH-EDTA). Therefore, this extract equals the sum of the first three Hedley fractions, not just EEP. That is, SRP was released from Al, Fe and ester bound states. 


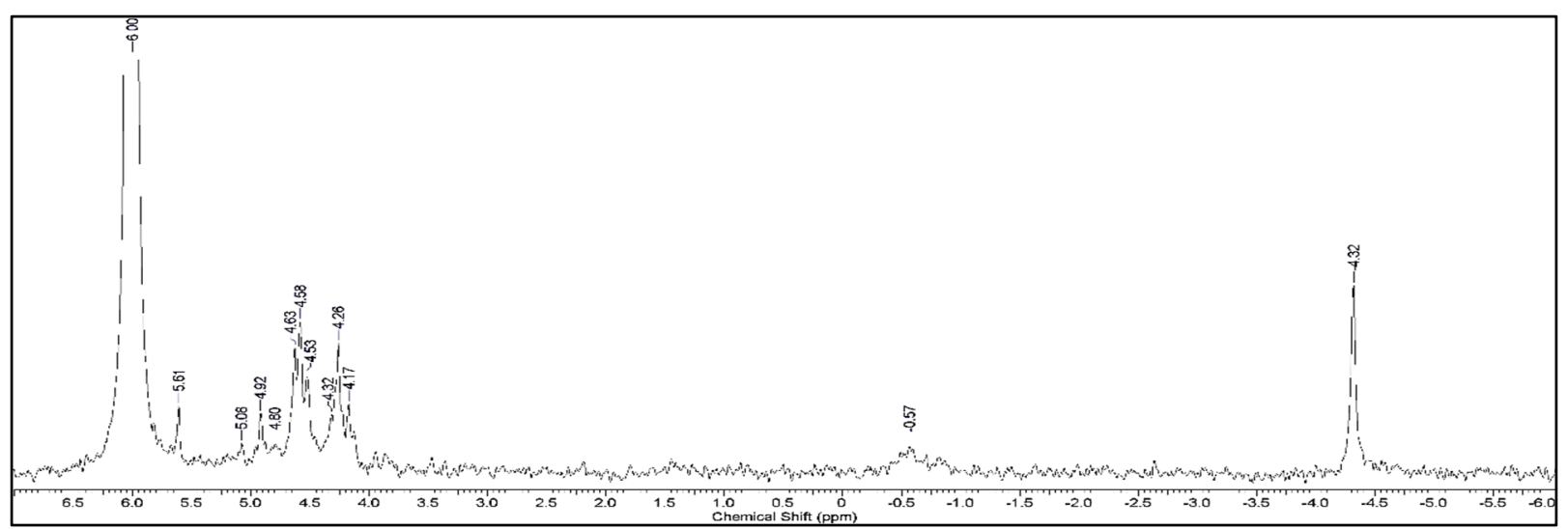

Figure 4. Proton decoupled ${ }^{31} \mathrm{P}$ NMR spectrum of phosphorus compounds in freshly excreted horse manure

\subsubsection{Phosphorus in various feed types}

Feed samples were analyzed for phosphorus using the Hedley fractionation scheme, as given earlier (Table 1). The horse feeds analyzed were Timothy and Alfalfa, Purina Pure Pride 100 horse chow, and Pasture Grasses as shown in Table 3.

These analyses gave P percentages (Table 3 ) in the range of $0.8-1.0 \% \mathrm{P}$, dry weight. The pasture grasses that we analyzed had about $0.94 \% \mathrm{P}$ which is higher than a variety of grasses $(0.23-0.44 \%-\mathrm{P})$ reported in Oklahoma and Virginia grasses (OKState, 2017; VTech, 2006).

The easily extracted phosphorus (EEP = water and bicarbonate extractant groups) of the feeds and pasture grasses was $46-63 \%$ of the total phosphorus content. The percent distribution of $\mathrm{P}$ in the various Hedley extractant fractions are given in Table 4 and graphically as Figure 5.

Table 4. Hedley fractionation analyses of certain equestrian feed materials

\begin{tabular}{|c|c|c|c|c|c|c|}
\hline & & & & & & "EEP" \\
\hline Sample & Extractant & Fraction & $\mathrm{mg}-\mathrm{PO}_{4}{ }^{3-} / \mathrm{kg}$ & $\mathrm{mg}-\mathrm{P} / \mathrm{kg}$ & $\% \mathrm{P}$ & $\mathrm{mg}-\mathrm{P} / \mathrm{kg}$ \\
\hline Timothy \& & $\mathrm{H}_{2} \mathrm{O}$ & SRP & 11,700 & 3,814 & 33.2 & $51.8 \%$ \\
\hline \multirow[t]{5}{*}{ Alfafa } & $\mathrm{NaHCO}_{3}$ & labile & 6,500 & 2,119 & 18.6 & \\
\hline & $\mathrm{NaOH}$ & $\mathrm{Al} \& \mathrm{Fe} \&$ esters & 6,200 & 2,021 & 17.6 & \\
\hline & $\mathrm{HCl}$ & $\mathrm{Ca} \& \mathrm{Mg}$ bound & 300 & 98 & 0.9 & \\
\hline & Digestion & organic & 8,700 & 2,836 & 29.7 & \\
\hline & & TOTAL & 33,400 & 10,888 & & \\
\hline Purina Pure & $\mathrm{H}_{2} \mathrm{O}$ & SRP & 13,100 & 4,271 & 49.5 & $62.8 \%$ \\
\hline \multirow[t]{5}{*}{ Pride-100 } & $\mathrm{NaHCO}_{3}$ & labile & 3,500 & 1,141 & 13.3 & \\
\hline & $\mathrm{NaOH}$ & $\mathrm{Al} \& \mathrm{Fe} \&$ esters & 5,000 & 1,630 & 18.9 & \\
\hline & $\mathrm{HCl}$ & $\mathrm{Ca} \& \mathrm{Mg}$ bound & 300 & 98 & 1.0 & \\
\hline & Digestion & organic & 3,000 & 978 & 17.3 & \\
\hline & & TOTAL & 24,900 & 8,117 & & \\
\hline Pasture & $\mathrm{H}_{2} \mathrm{O}$ & SRP & 9,900 & 3,227 & 32.2 & $45.6 \%$ \\
\hline \multirow[t]{5}{*}{ Grasses } & $\mathrm{NaHCO}_{3}$ & labile & 4,100 & 1,337 & 13.4 & \\
\hline & $\mathrm{NaOH}$ & $\mathrm{Al} \& \mathrm{Fe} \&$ esters & 11,800 & 3,847 & 38.5 & \\
\hline & $\mathrm{HCl}$ & $\mathrm{Ca} \& \mathrm{Mg}$ bound & 700 & 228 & 2.3 & \\
\hline & Digestion & organic & 2,300 & 750 & 13.7 & \\
\hline & & TOTAL & 28,800 & 9,389 & & \\
\hline
\end{tabular}

EEP $=$ Easily Extracted Phosphorus (= SRP plus labile). 
Table 5. Comparison of the phosphorus species (Hedley fractions) between various feedstocks and horse manure

\begin{tabular}{lllllll}
\hline \multicolumn{7}{c}{ Percentages } \\
\hline & Water & Bicarb & $\mathrm{NaOH}$ & $\mathrm{HCl}$ & Digest & EEP \\
\hline T\&A & 33.2 & 18.6 & 17.6 & 0.9 & 29.7 & 51.8 \\
Purina-100 & 49.5 & 13.3 & 18.9 & 1.0 & 17.3 & 62.8 \\
Grasses & 32.2 & 13.4 & 38.5 & 2.3 & 13.7 & 45.6 \\
Manure Avg. & 39.8 & 18.4 & 24.4 & 2.3 & 15.1 & 58.2 \\
\hline
\end{tabular}

$\mathrm{EEP}=$ Easily Extractable Phosphorus $=$ Water plus mild aqueous bicarbonate

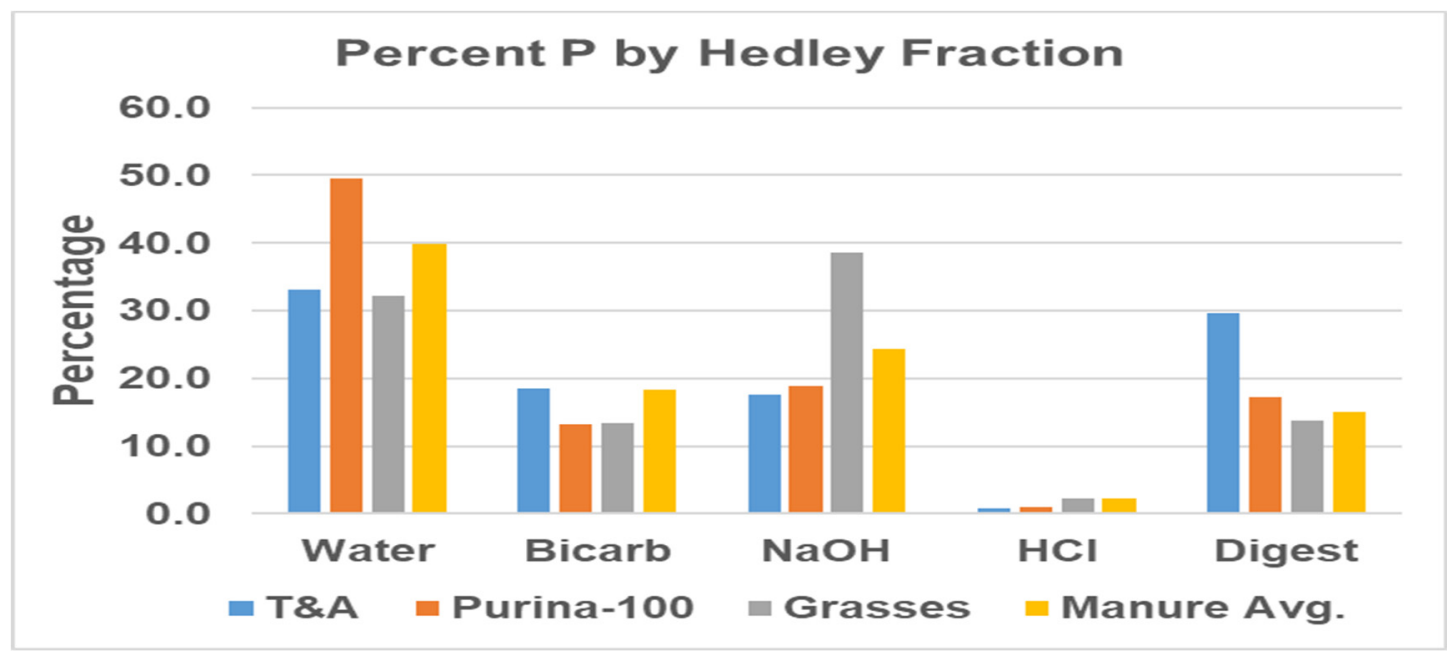

Figure 5. Graphic representation of phosphorus species (Hedley fractions) between feed stock and horse manure

An additional feed sample (Nutrena Proforce Senior ${ }^{\circledR}$ ) was analyzed in triplicate only for total phosphorus using ICP-OES and it was found to have $6,340 \pm 300 \mathrm{mg} / \mathrm{kg}-\mathrm{P}$, dry weight.

Given that this was a limited sample of horse feeds, TP can be noted to range from about 6,000 - 11,000 mg-P (6$11 \mathrm{~g}-\mathrm{P} ; 0.6-1.1 \%$ ) per kilogram of various feed materials.

\subsubsection{Horse paddock soil phosphorus with depth}

Certain manure samples ("CC") were taken from a horse field where we also investigated phosphorus quantity and fractions versus soil depth. This field was in the Town of Loxahatchee Groves and the soils sampled are of the Riviera Association and have been described as being "nearly level, poorly drained sandy soils that have a loamy subsoil starting at around 2 feet (McCollum et al., 1978). The loamy subsoil was below our deepest $(12 \mathrm{~cm})$ sample level. We compared soil phosphorus fractions (Table 5) with the average values of manure samples CC\#1-fresh and CC\#1-aged (see Table 2-above). It is noted here that the soil cores studied (Table 6) were not directly under a manure pile. That is, this was a site within an actively horse occupied field and the history of manure immediately at the core site is unknown. 
Table 6. Mass (mg-P / g soil) of phosphorus in Hedley fractions of sandy soil, including comparison to the average of fresh and aged horse manure samples

\begin{tabular}{lllllll}
\hline \multicolumn{7}{c}{$\mathrm{mg}-\mathrm{P} / \mathrm{g}$} \\
\hline & $\mathrm{H} 2 \mathrm{O}$ & $\mathrm{NaHCO}_{3}$ & $\mathrm{NaOH}$ & $\mathrm{HCl}$ & Digest & TOTAL \\
\hline (Manure) & 6.087 & 2.824 & 3.730 & 0.358 & 2.303 & 15.302 \\
$0.0-1.2$ & 0.067 & 0.254 & 1.827 & 0.013 & 0.119 & 2.280 \\
$1.2-2.3$ & 0.066 & 0.217 & 1.328 & 0.091 & 0.169 & 1.871 \\
$2.3-3.4$ & 0.067 & 0.105 & 0.143 & 0.005 & 0.029 & 0.348 \\
$3.4-4.5$ & 0.040 & 0.070 & 0.091 & 0.004 & 0.065 & 0.270 \\
$4.5-5.6$ & 0.058 & 0.142 & 0.304 & 0.015 & 0.120 & 0.638 \\
$5.6-6.7$ & 0.076 & 0.148 & 0.329 & 0.005 & 0.023 & 0.580 \\
$6.7-7.8$ & 0.053 & 0.166 & 0.332 & 0.008 & 0.044 & 0.604 \\
$7.8-8.9$ & 0.067 & 0.105 & 0.323 & 0.009 & 0.074 & 0.578 \\
$8.9-11.0$ & 0.074 & 0.113 & 0.345 & 0.016 & 0.134 & 0.681 \\
$11.0-12.0$ & 0.062 & 0.092 & 0.253 & 0.007 & 0.068 & 0.482 \\
\hline
\end{tabular}

From both the raw data (Tables $5 \& 6$ ) and their graphical representations (Figures 6a-b), it can be seen that there was a rapid decline in the amount of soil phosphorus below $2.3 \mathrm{~cm}$. The largest decline was found to be in the sodium hydroxide extracted fraction, which contains $\mathrm{Al}$ and Fe bound phosphate plus mono- and di-ester phosphates (Dou et al., 2000; Hedley et al., 1982).
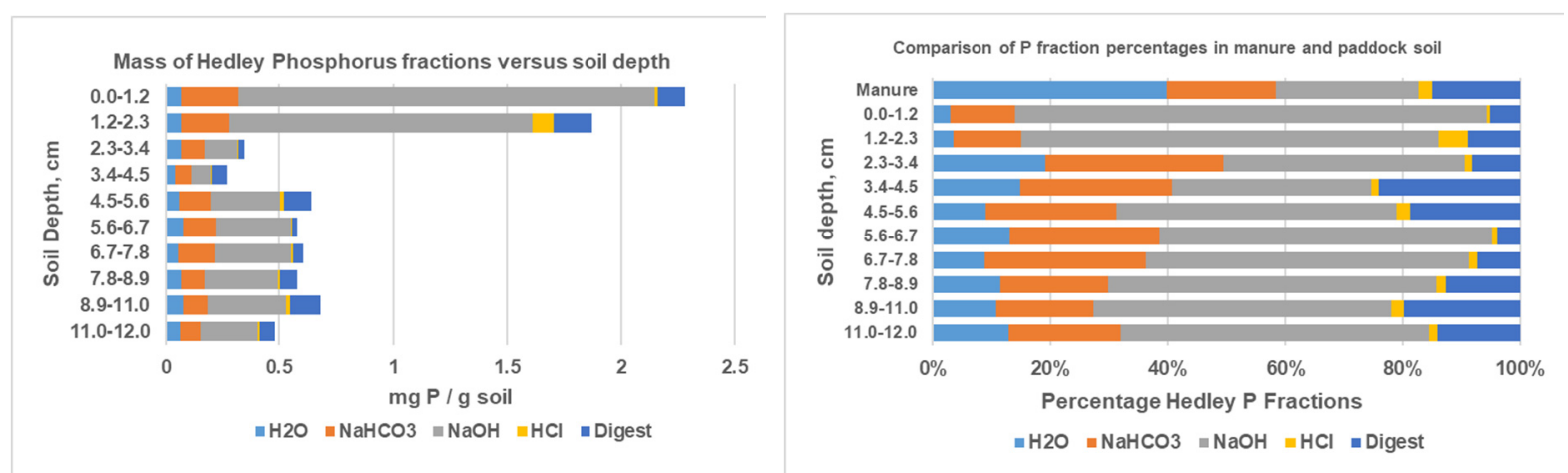

Figure 6. Phosphorus fractions in soil. (a) Mass versus depth.

(b) Hedley $\mathrm{P}$ fraction percentages versus depth and compared to horse manure

\subsubsection{Tests for Calcium Sequestration of Phosphate}

As phosphorus runoff and/or percolation from equestrian and agricultural lands will enter the numerous canals in south Florida, the influence of limestone will affect its mobility and/or sequestration. We performed a simple test to see how two different forms of calcite $\left(\mathrm{CaCO}_{3}\right)$, fine grained or chunks, alters SRP solubility. Manure samples were placed into $100.0 \mathrm{~mL}$ of either deionized or Loxahatchee Groves canal water and then steeped with the added calcite in the dark for one week. The P-polluted canal water had $3.728 \mathrm{mg}-\mathrm{P} / \mathrm{L}$ (3,728 ppb-P) before the addition of manure. The resultant data are given in Table 7 . 
Table 7. Reaction of phosphate (SRP, ortho-phosphate) with calcium carbonate (Calcite)

\begin{tabular}{lllll}
\hline & \multicolumn{2}{c}{ 100mL Deionized water } & \multicolumn{2}{c}{ 100mL Canal water } \\
\hline & \multicolumn{2}{c}{ plus 10.01g } & "JO" manure & \multicolumn{2}{c}{ plus 10.01g "JO" manure } \\
\hline Sample & \multicolumn{2}{l}{ SRP mg-P / L } & Percent & \multicolumn{2}{c}{ SRP mg-P / L } & Percent \\
\hline Plain & 6.793 & $100.0 \%$ & 10.519 & $100.0 \%$ \\
10g Fine & 0.409 & $6.0 \%$ & 0.489 & $46.0 \%$ \\
25g Fine & 0.319 & $4.7 \%$ & 0.369 & $3.5 \%$ \\
10g chunk & 5.276 & $77.7 \%$ & 8.361 & $79.5 \%$ \\
25g chunk & 5.218 & $76.8 \%$ & 7.984 & $75.9 \%$ \\
100g chunk & 3.748 & $55.2 \%$ & 7.289 & $69.3 \%$ \\
\hline
\end{tabular}

\subsubsection{Phosphorus in Canal Waters}

Neighboring the Village of Wellington to the north is the Town of Loxahatchee Groves Florida $\left(26^{\circ} 42^{\prime} 56^{\prime \prime} \pm \mathrm{N} x\right.$ $80^{\circ} 16^{\prime} 23^{\prime \prime} \pm \mathrm{W}$ ) which has over 29 miles of canals within its 12.5 square mile area and these drain into the Palm Beach Canal (SFWMD \#C-51). The C-51 canal moves water to the west towards South Florida Water Management's stormwater treatment areas (STAs) and the Greater Everglades and to the east towards Lake Worth Lagoon.

Study of phosphorus pollution in these canals, as well as certain other sites in south Florida, was driven by observations of excess utilization of horse manure and urine/manure soaked stall pine wood chip bedding on agricultural properties. During routine agricultural fertilization the N:P:K contents of industrial fertilizers are known and their application can occur in line with BMPs and minimally required additions. However, the use of horse manure and bedding occurs with unknown N:P:K concentrations and often unregulated spreading. That is, agricultural operations are allowed to receive manure / bedding and in so doing also receive a 'tipping fee'. That is, the hauler pays the receiver a certain amount per load and often the receiver takes much more than is actually needed to just supply good nutrient levels for plant growth. Figures $7 \mathrm{a}-\mathrm{b}$ are presented to emphasize this point. The swales alongside the dirt roads drain into the canals discussed here.

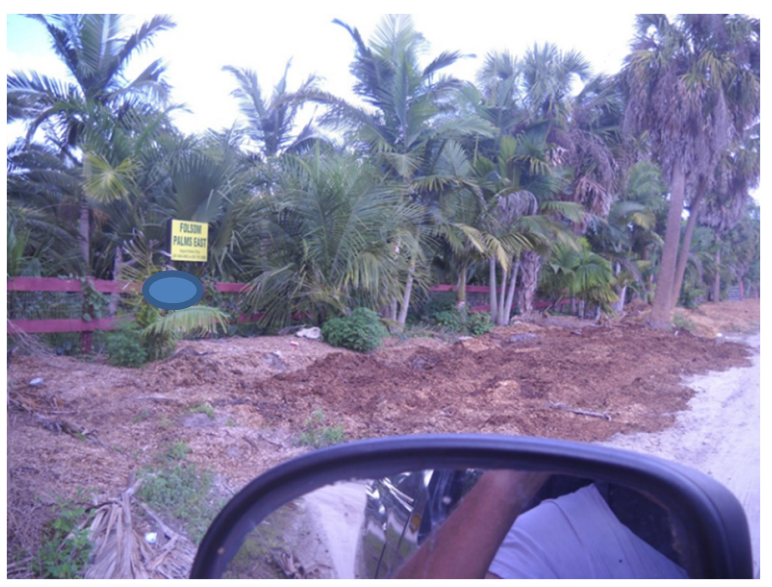

(a)

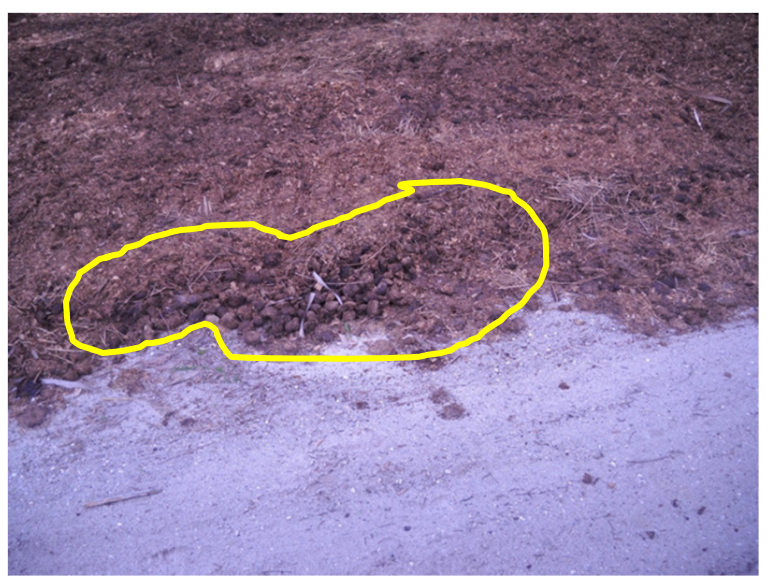

(b)

Figure 7. Excessive use of equestrian manure and bedding. (a) A palm tree nursery that received and spread equestrian bedding and manure several feet thick over entire property and into adjacent drainage swale. (b)

Close-up of equestrian waste in the swale adjacent to a road with obvious horse manure circled

(Photographs by senior author).

Well over a dozen canal sites were randomly sampled. Looking only at the SRP (EEP) values, September samples ranged from 10-268 with a mean of 56 ppb-P and October samples ranged from 47-262 ppb with a mean of 103 ppb-P. The lower values equated to sites receiving back-pumped waters from the $\mathrm{C}-51$ canal during the equestrian 
off-season months. However, once the equestrian season got well underway and wastes were received from nearby equestrian activities the range went to $78-797 \mathrm{ppb}-\mathrm{P}$ with a mean of $238 \mathrm{ppb}-\mathrm{P}$. We sampled the water coming from an outflow pipe of a nursery that had 3-4 feet of equestrian wastes piled up on a 20 acre site. In this case, SRP was $7,958 \mathrm{ppb}-\mathrm{P}(24,410 \mathrm{ppb}-\mathrm{PO} 4)$ or $8 \mathrm{mg}-\mathrm{P} / \mathrm{L}$. Finding such a high level led to a resampling a few weeks later. In that case SRP was $4.84 \mathrm{mg} / \mathrm{L}(4,840 \mathrm{ppb}-\mathrm{P})$ and TP was $4.96 \mathrm{mg} / \mathrm{L}$ (4,960 ppb-P). SRP was therefore $97.6 \%$ of TP. Summing nitrate and nitrate values in these outflow waters gave an atomic N:P ratio of $<1: 1$. Water from a site about 1 mile from this outflow pipe had SRP at $340 \mathrm{ppb}-\mathrm{P}$ and an atomic N:P ratio of $\sim 7: 1$. Such high P pollution certainly would favor diazotrophic (nitrogen-fixing) cyanobacteria. Indeed, we microscopically identified Lyngbya sp. in these canals. During a different year, we sampled 24 sites within the 24 miles of canals (i.e. 1 sampling per mile) of Loxahatchee Groves and found a range of $32-1,670 \mathrm{ppb}$ as phosphate ( $=10-604 \mathrm{ppb} \mathrm{P})$ in the canal waters. This reinforces the concept that non-point sourcing of $\mathrm{P}$ pollution needs attention if such pollution is ever to be controlled.

\subsection{Discussion}

Overall, horse manure yielded easily extracted phosphorus (EEP) that was $54-77 \%$ of the total phosphorus. Total phosphorus ranged from 13,020 - 22,300 mg per kilogram dry weight. That is, 13-22 grams of P per kilogram of manure. That equates to $6-10$ grams of $\mathrm{P}$ per pound and 12,000 - 20,000 grams ( $26-44$ pounds) of $\mathrm{P}$ per ton of manure ( $\approx 60-100 \mathrm{lbs}$. $\mathrm{P}_{2} \mathrm{O}_{5} /$ ton), dry weight. Looking at wet weight values, this equates to 4.4 to $16.3 \mathrm{~g}-\mathrm{P} / \mathrm{kg}$ manure, wet weight. Therefore, on the wet weight basis, this equates to 4,000 to 14,818 grams-P/ U.S. ton or 8.8 to 32.6 pounds of phosphorus $\left(\approx 20-75 \mathrm{lb} . \mathrm{P}_{2} \mathrm{O}_{5}\right)$ per wet weight ton of horse manure. These values overlap the horse manure yield of 0.03-0.05 lb.- $\mathrm{P}_{2} \mathrm{O}_{5} / \mathrm{lb} .(\approx 60-100 \mathrm{lb} . /$ ton$)$ reported by others (e.g. NOLA, 2020; UMinn, 2020).

Given that EEP and organic phosphorus species comprise the vast majority $(\sim 80 \%)$ of $\mathrm{P}$ in horse manure, the potential for rain and irrigation extraction and runoff / percolation can easily account for a highly significant "nonpoint" source of $\mathrm{P}$ pollution in surficial aquifers and open water systems.

Overall, values of about 5 to $>20$ g-P/kg- horse manure dry weight with about $55-75 \%$ ( 2 to $>11 \mathrm{~g}$-EEP $/ \mathrm{kg}$ dry wt.) of that being Easily Extractable Phosphorus can be concluded. Additionally, it can be stated that rather high variability in the amount of total (TP) and easily extractable (EEP) phosphorus exists when analyzing horse manure. This likely stems from the diet of the horse, the horse type and age, the freshness of the samples, the moisture content, and a myriad of other factors.

The fractionation of TP pools can be coupled with P speciation through ${ }^{31} \mathrm{P}$ NMR spectroscopy to give a much more in-depth understanding of the biogeochemical dynamics of $\mathrm{P}$, which distinguish individual $\mathrm{P}$ compounds in the fractionated P pools from horse manure (Turner and Leytem, 2004; McDowell and Stewart, 2006).

Along with mineral $(\mathrm{Al}, \mathrm{Fe}, \mathrm{Ca}, \mathrm{Mg})$ bound $\mathrm{P}$, organic $\mathrm{P}\left(\mathrm{P}_{\mathrm{o}}\right)$ is a $\mathrm{P}$ source that is available for future bio-/geochemical conversions to SRP and release for immediate in situ bioavailability and/or movement into surface waters. Ortho-phosphate (SRP) was found to be the vastly major (80.8\%) component with -glycerol-phosphate (5.7\%), phytic acid (4.8\%) pyrophosphate (4.0\%) and DNA (2.7\%) also being present. SRP is regraded as the easily leachable / mobile phosphorus with respect to the P pollution of ground water and nearby surface waters (canals, lakes etc.). It is noted here that -glycerol-phosphate and pyrophosphate can be hydrolyzed to ortho-phosphate $(=\mathrm{SRP})$

Given that we analyzed a limited sample of horse feeds, TP can be noted to range from about 6,000-11,000 mgP (6-11 g-P; $0.6-1.1 \%)$ per kilogram of various feed materials.

The large yield and percentage of the Al-, Fe- and mono-/di-ester phosphates ( $\mathrm{NaOH}$ extract) in the soil, especially in the top several centimeters, may reflect retention of those forms from field grasses / roots (see feed results: Table 5, Fig, 6) and/or sequestration of SRP by Al and Fe in the soil. Compared to the horse manure (Figure 6b), considered here to be a major P source by leaching / runoff transport, the percent loss of SRP in the surface $2.3 \mathrm{~cm}$ can be envisioned as being due to surface runoff and/or sequestration by $\mathrm{Al}$ and $\mathrm{Fe}$. The minor amounts and percentages of $\mathrm{Ca}$ and $\mathrm{Mg}$ bound $\mathrm{P}(\mathrm{HCl}$ extract) reflects the low $\mathrm{Ca} / \mathrm{Mg}$ content of the Rivera Association sandy soils in this field. Future studies should compare wet and dry seasons to obtain information of the mobilization of SRP and the leaching and/or breakdown of the easily labile $\mathrm{P}$ forms, such as pyro-phosphate. This area of Florida normally averages about 60 inches of rain per year (FCC, 2020) and, given the majority of that occurring in the wet season (May - October), significant runoff can be expected. Future studies of P input to soils from overlying manure needs to consider soil geochemistries and rain history.

Fined grained calcium carbonate, a surrogate for powdered 'limestone', was found to effectively (avg. 95-96\%) 
remove phosphate from pure as well as high COD canal waters. This contrasts with the calcite chunks which, even at a 4-fold mass increase (viz. 100 vs. 25 g), removed only 30-45\% of the SRP. This difference (50-60\%) reflects the difference in available surface area between the fine-grained (high area/g) and chunk (low area/g). Future studies should repeat this test with native limestones. It is suggested here that limestone pebbles, that is neither powder nor large chunks, be utilized to fill a trough around equestrian paddocks and agriculture fields in order to intercept and immobilize phosphate that leaches from the field, forming a non-point source. The use of limestone pebbles to form a "French Drain" at the font of manure / bedding collection bins (Figure 8) would capture significant SRP runoff and could enhance current and planned best management practices (BMPs).

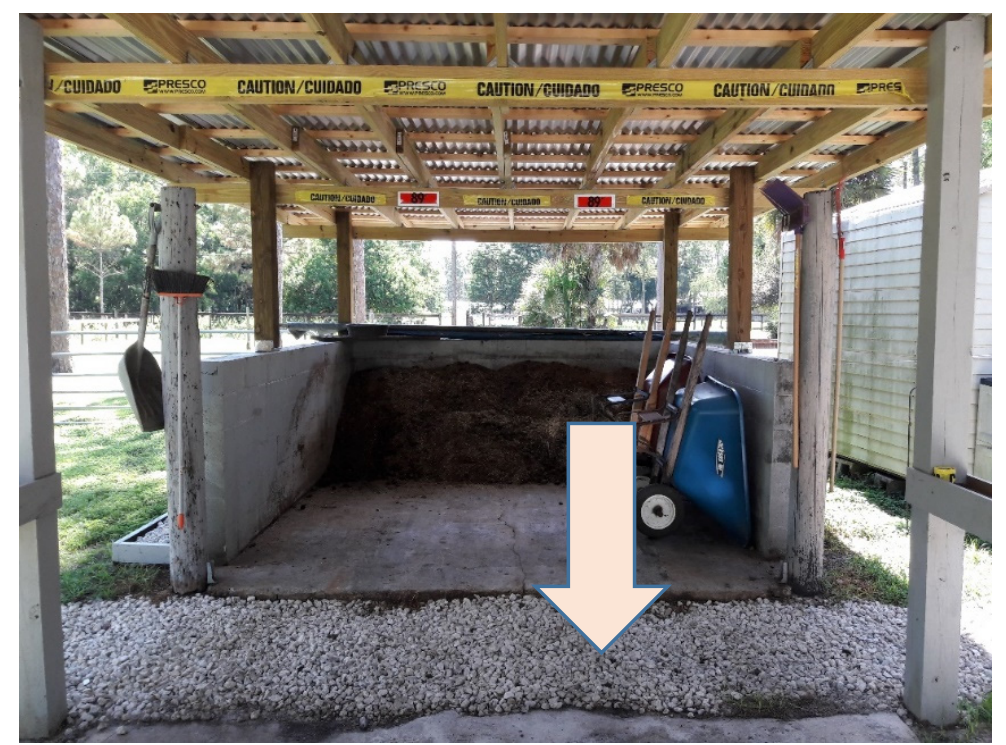

Figure 8. Picture of a manure / barn bedding collection / storage area established to lessen rain induced leeching. Limestone pebbles form a "French Drain" at the front

The Village of Wellington (Ordinance 2012-12 Amended Chapter 30, Article V), the Town of Loxahatchee Groves Ordinance 2010-003) and Palm Beach County (Ordinance 2017-005) have all passed ordinances covering equestrian waste haulers and dumping. These efforts certainly help and best management practices (BMPs) are evolving. However, the spreading of manure and bedding, such as occurred on thousands of acres of U.S. Sugar lands with "little resultant agricultural benefit" (as cited in Palm Beach Post 9/21/2020, p. 5B), is not the answer. Rather, recycling such that the manure and urine organic matter plus plant nutrient elements (N, P, K, Fe etc.) are pelletized and sold as fertilizer with a known N:P:K value and the wood bedding chips are cleaned and resold as bedding is the ultimate way to handle the hundreds of thousands of tons of equestrian waste. Palm Beach County recently approved a recycling facility to be operated by a private company on land leased from the Palm Beach County Solid Waste Authority (Bukley, 2020; Morse, 2020).

We need to point out another aspect of recycling. That is, it needs to be as close to the major sites of generation as possible in order to cut down on the addition of excess carbon dioxide and sulfur oxides from heavy diesel truck traffic. The average mileage of a class 8 a diesel dump truck is $3-7 \mathrm{mpg}$ (US-DOE, 2015). Using the median value of $5 \mathrm{mpg}$, one truck puts 22.2 pounds of carbon dioxide per mile into the atmosphere. That is 111 pounds of carbon dioxide per 25 mile trip. Hence, shorter trips to and from major sites of generation would cut down on climate change. Additionally, diesel soot is heavy in particulate matter of the 2.5-micron size (PM2.5) which is a lung problem, especially for asthmatics and the young (Balmes, 2011; Ris, 2007; Salvi et al., 1999).

\section{Conclusions}

The extremely high soluble reactive P (SRP), aka easily extracted phosphorus (EEP), concentrations found in horse manure, shown in Tables 2-3, leads to large amounts of $\mathrm{P}$ pollution from water runoff. This we found in Palm Beach County canal waters when equestrian activities and the indiscriminant waste spreading on adjacent lands was high (cf. Giles et al., 2015). As high amounts of P leaching into water sources occurs, eutrophic conditions and large micro-/ macro-algal and higher plant aquatic blooms may follow. Additionally, $\mathrm{Al}$ and $\mathrm{Fe}$ seem to play a role as $\mathrm{P}$ short-term storage while $\mathrm{Ca}$ and $\mathrm{Mg}$ lead to somewhat longer-term storage for $\mathrm{P}$ (Table 6). Organic phosphorus $\left(\mathrm{P}_{\mathrm{o}}\right)$ species made up from 4.5 to $15.3 \%$ of the total phosphorus in several horse manure samples (Table 
2). These $P_{o}$ species are also water mobile and, through hydrolysis, give rise to highly soluble ortho-phosphate or are then bound to metals $(\mathrm{Fe}, \mathrm{Al}, \mathrm{Ca}, \mathrm{Mg})$. Through nutrient analyses and $\mathrm{P}$ speciation studies, future studies should be able to determine how $\mathrm{P}$ types are transported through the ecosystems that feed the Everglades, Lake Worth Lagoon, and adjacent bodies of water. Plant uptake is the main factor in the fate of labile P (Duersch et al., 2020 and references therein). Knowing the different $\mathrm{P}$ pools present in the environment should help guide the management of $\mathrm{P}$ containing wastes and soil amendments (Condron and Newman, 2011). However, it may take years to remove substantial amounts of the so-called 'legacy' phosphorus (Gatiboni et al., 2020; Havens and Thomas, 2005; Lou et al., 2018; Pavinato et al., 2020) out of the soil to the point where dissolved P in runoff is effectively reduced (McCollum, 1991; Meals et al., 2010; Zhang et al., 2004; Sharpley et al., 2013).

The quite often excessive utilization of animal waste, equestrian in the present study, as landfill / fertilizer does not allow accurate tracing of N:P:K soil amendment and also leads to significant nutrient pollution of adjacent waters. Recycling of equestrian waste whereby the wood bedding chips are cleaned and reused and the manure / urine materials are processed into pellets with known N:P:K concentrations can then allow for enhanced fertilization best management practices.

\section{Acknowledgements}

Portions of these studies were funded by the senior author's research accounts stemming from unrelated contracts with the South Florida Water Management District and directly by a donation from the 4Ocean organization. Dr. B. Duersch acknowledges support from a grant from the Everglades Foundation, which was awarded during his $\mathrm{Ph}$.D. dissertation research in the senior author's group. Certain parts of these studies were also supported by FAU Departmental funds covering Directed Independent Study projects of our undergraduate student co-authors (CC, VQ, LC, and JO). We thank Ms. Laura Danowski of Loxahatchee Groves for allowing JWL to photograph and use the picture of her manure / bedding collection bin.

\section{References}

Antonius, G., Turley, E., \& Dawood, M. (2019). Ascorbic acid, sugars, phenols, and nitrate concentrations in tomato grown in animal manure amended soil. Agriculture, 9, 94. https://doi.org/10. 3390/agriculture9050094

Arnold, J. G., Srinivasan, R., Muttiah, R. S., \& Williams, J. R. (1998). Large area hydrologic modeling and assessment part I: model development1. Journal of the American Water Resources Association, 34, 73-89. https://doi.org/10.1111/j.1752-1688.1998.tb05961.x

Badruzzaman, M., Pinzon, J., Oppenheimer, J., \& Jacangelo, J. C. (2012). Sources of nutrients impacting surface waters in Florida: A Review. Journal of Environmental Management, 109, 80-92.

Balmes, J. R. (2011). How does diesel exhaust impact asthma? Thorax, 66, 4-6.

Boggess, W. G., Johns, G., \& Meline, C. (1997). Economic impacts of water quality programs in the Lake Okeechobee watershed of Florida. Journal of Dairy Science, 80, 2682-2691.

Bruland, G. L., Osborne, T. Z., Reddy, K. R., Grunwald, S., Newman, S., \& DeBusk, W. F. (2007). Recent changes in soil total phosphorus in the Everglades: Water Conservation Area 3. Environmental Monitoring and Assessment, 129, 379-395. https://doi.org/10.1007/s10661-006-9371-x

Bukley, R. (2020). County Zoners Recommend Approval of Manure Recycling Plant in Industrial Area. Retrieved from https:/gotowncrier.com/2020/11/county-zoners-recommend-approval-of-manure-recycling-plant-inindustrial-area/

Cade-Menun, B., \& Liu, C. W. (2014). Solution Phosphorus-31 Nuclear Magnetic Resonance Spectroscopy of Soils from 2005 to 2013: A Review of Sample Preparation and Experimental Parameters. Soil Science Society of America Journal, 78, 19-37. https://doi.org/10.2136/sssaj2013.05.0187dgs

Cade-Menun, B. J. (2015). Improved peak identification in 31P-NMR spectra of environmental samples with a standardized method and peak library. Geoderma, 257-258, 102-114. https://doi.org/10.1016/j.geoderma.2014.12.016

Capone, G. M. (2019). Equestrian Committee discusses crosswalks, manure disposal. Town-Crier Newspaper May 10-16. P. 4.

Carpenter, S. R., Caraco, N. F., Correll, D. L., Howarth, R. W., Sharpley, A. N., \& Smith, V. H. (1998). Nonpoint pollution of surface waters with phosphorus and nitrogen. Ecological Applications, 8, 559-568. https://doi.org/10.1890/1051-0761(1998)008[0559:NPOSWW]2.0.CO;2

Childers, D. L., Doren, R. F., Jones, R., Noe, G. B., Rugge, M., \& Scinto, L. J. (2003). Decadal change in vegetation 
and soil phosphorus pattern across the Everglades landscape. Journal of Environmental Quality, 32, 344-362. https://doi.org/10.2134/jeq2003.3440

Cintron, C., \& Louda, J. W. (2007). Extractability of phosphorous from horse manure and implications for the pollution of the surficial waters and aquifers of southern Florida. $71^{\text {st }}$. Annual Meeting of the Florida Academy of Sciences. St. Petersburg, FL. March 16-17. Abstr. ENV.

Concepcion, A., Kumaragamage, D., Akinremi, W., Dharmakeerthi, S., Goltz, D., \& Indraratne, S. (2021). Phosphorus release from intact soil monoliths of manure-amended fields under simulated snowmelt flooding. Journal of Environmental Quality, 50, 252-263. https://doi.org/10.1002/jeq2.20179

Condron, L. M., \& Newman, S. (2011). Revisiting the fundamentals of phosphorus fractionation of sediments and soils. Journal of Soils and Sediments, 11(5), 830-840. https://10.1007/s11368-011-0363-2

Corrales, J., Naja, G. M., Bhat, M. G., \& Miralles-Wilhelm, F. (2014). Modeling a phosphorus credit trading program in an agricultural watershed. Journal of Environmental Management, 143, 162-172. https://doi.org/10.1016/j.jenvman.2014.04.031

Cosgrove, D. J. (1980). The determination of myo-inositol hexkisphosphate (phytate). Journal of the Science of Food and Agriculture. 31, 1253-1256. https://doi.org/10.1002/jsfa.2740311206

Dersjant-Li, Y., Awati, A., Schulze, H., \& Partridge G. (2015). Phytase in non-ruminant animal nutrition: a critical review on phytase activities in the gastrointestinal tract and influencing factors. Journal of the Science of Food and Agriculture, 95, 878-896. https://doi.org/10.1002/jsfa.6998

Dou, Z., Toth, J. D., Galligan, D. T., Ramberg, C. F., \& Ferguson, J. D. (2000). Laboratory procedures for characterizing manure phosphorus. Journal of Environmental Quality, 29, 508-514. https://doi.org/10.2134/jeq2000.00472425002900020019x

Drohan, P. J., Bechmann, M., Buda, A., Djodjic, A., Doody, D., Duncan, J. M., Iho, A., Jordan, P., Kleinman, P. J., Mellander, P.-E., Thomas, I. A., \& Withers, P. J. A. (2019). A Global perspective on phosphorus management decision support in agriculture: Lessons learned and Future directions. Journal of Environmental Quality, 48, 1218-1233. https://doi.org/10.2134/jeq2019.03.0107

Duersch, B. G. (2020). Phosphorus Sequestration and Bioremediation: Phosphorus-31 Nuclear Magnetic Resonance Spectroscopy. Ph.D. Dissertation, Department of Chemistry and Biochemistry, Florida Atlantic University, Boca Raton, Florida.196 pp.

Duersch, B. G., \& Louda, J. W. (2017). Phosphorus speciation using 31P nuclear magnetic resonance spectroscopy in order to trace phosphorus sources and movement in the northern Florida everglades and the C51 basin. $254^{\text {th }}$. ACS National Meeting and Exposition. Washington, D.C. Abstract ANYL-79.

Duersch, B. G., Bhadha, J. H., Root, T., \& Louda, J. W. (2020). The role of rice (Oryza sativa L.) in sequestering phosphorus compounds and trace elements: Speciation and dynamics. Science of the Total Environment, 725, 138366. https://doi.org/10.1016/j.scitotenv.2020.138366

Edwards, D. R., Moore Jr., P. A., Workman, S. R., \& Busheé, E. L. (1999). Runoff of metals from alum-treated horse manure and municipal sludge. Journal of the American Water Research Association, 35, 155-165. https://doi.org/10.1111/j.1752-1688.1999.tb05460.x

Elser, J. J., Bracken, M. E. S., Cleland, E. E., Gruner, D. S., Harpole, W. S., Hillebrand, H., Ngai, J.T., Seabloom, E. W., Shurin, J. B., \& Smith, J. E. (2007). Global analysis of nitrogen and phosphorus limitation of primary producers in freshwater, marine and terrestrial ecosystems. Ecology Letters, 10, 1135-1142. https://doi.org/10.1111/j.1461-0248.2007.01113.x

Entry, J. A., \& Gottlieb, A. (2014). The impact of stormwater treatment areas and agricultural best management practices on water quality in the Everglades Protection Area. Environmental Monitoring and Assessment, 186, 1023-1037. https://doi.org/10.1007/s10661-013-3436-4

FCC. (2020). Florida Climate Center at Florida State University. Retrieved from https://climatecenter.fsu.edu/products-services/data/1981-2010-normals/west-palm-beach

FDACS. (2011). Water Quality/Quantity Best Management Practices for Florida Equine Operations. Florida Department of Agriculture and Consumer Services. Tallahassee, Florida. DACS-P-01531. 69pp. Retrieved from https://www.fdacs.gov/content/download/30687/file/equineBMP-lores.pdf

FDEP. (2013). Small Scale Horse Operations: Best Management Practices for Water Resource Protection in Florida. Florida Department of Environmental Protection, Tallahassee, Florida, $40 \mathrm{pp}$. Retrieved from 
https://floridadep.gov/water/industrial-wastewater/documents/bmps-small-scale-horse-operations.pdf

FDOH. (2013). Florida Department of Health. Onsite Sewerage Treatment and Disposal Systems installed in Florida. Retrieved from http://www.floridahealth.gov/environmental-health/onsite-sewerage/newinstallations.pdf

Fisher, M. M., Reddy, K. R., \& James, R. T. (2005). Internal nutrient loads from sediments in a shallow, subtropical lake. Lake and Reservoir Management, 21, 338-349. https://doi.org/10.1080/07438140509354439

FlaSpec. (2017). Palm Beach County creates new land use category for recycling of equestrian wastes. Florida Specifier, Goldenrod, Florida. March, 39(3), 7. Retrieved from https://www.enviro-net.com/fullaccess/issues/

Flores, P., Castellar, I., Hellin, P., Fenoli, J., \& Navarro, J. (2007). Response of pepper plants to different rates of mineral fertilizers after soil biofumigation and solarization. Journal of Plant Nutrition, 30, 367-379. https://doi.org/10.1080/01904160601171264

Fowler, A. L., Hansen, T. L., Strasinger, L. A., Harlow, B. E., \& Lawrence, L. M. (2015). Phosphorus digestibility and phytate degradation by yearlings and mature horses. Journal of Animal Science, 93, 5735-5742. https://doi.org/10.2527/jas.2015-9139

Gatiboni, L., Brunetto, G., Pavinato, P. S., \& George, T. S. (2020). Editorial: Legacy Phosphorus in Agriculture: Role of Past Management and Perspectives for the Future. Frontiers in Earth Science, 8, 619935. https://doi.org/10.3389/feart.2020.619935

Giles, C. D., Cade-Menun, B. J., Liu, C. W., \& Hill, J. E. (2015). The short-term transport and transformation of phosphorus species in a saturated soil following poultry manure amendment and leaching. Geoderma, 257258. https://doi.org/10.1016/j.geoderma.2014.08.007

Gobler, C. J., Burkholder, J. M., Davis, T. W., Harke, M. J., Johengen, T., Stow, C. A., \& VanDeWaal, D. B. (2016). The dual role of nitrogen supply in controlling the growth and toxicity of cyanobacterial blooms. Harmful Algae, 54, 87-97. https://doi.org/10.1016/j.hal.2016.01.010

Guignard, M. G., Leitch, A. R., Acquisti, C., Eizaguirre, C., Elser, J. J., Hessen, D. O., Jeyasingh, P. D., Neiman, M., Richardson, A. E., Soltis, P. S., Soltis, D. E., Stevens, C. J., Trimmer, M., Weider, L. J., Woodward, G., \& Leitch, I. J. (2017). Impacts of nitrogen and phosphorus: From genomes to natural systems and agriculture. Frontiers in Ecology and Evolution, 5(70). https://doi.org/10.3389/fevo.2017.00070

Gunsalus, B., Flaig, E. G., \& Ritter, G. (1992). Effectiveness of agricultural best management practices implemented in the Taylor Creek/Nubbin Slough Watershed and the Lower Kissimmee River Basin. p. 161171. In The National Rural Clean Water Program Symp., September 1992. Orlando, FL. ORD EPA/625/R92/006. USEPA, Washington, DC. from https://cfpub.epa.gov/si/si_public_record_Report.cfm?Lab=ORD\&dirEntryID $=46328$

Hart, M. R., \& Cornish, P. S. (2012). Available soil phosphorus, phosphorus buffering and soil cover determine most variation in phosphorus concentration in runoff from pastoral sites. Nutrient Cycling in Agroecosystems, 93, 227-244. https://doi.org/10.1007/s10705-012-9512-2

Havens, K. E. (1995). Secondary nitrogen limitation in a subtropical lake impacted by non-point source agricultural pollution. Environmental Pollution, 89, 241-6. https://doi.org/10.1016/0269-7491(94)00076-P

Havens, K. E., \& East, T. (1997). In Situ Responses of Lake Okeechobee (Florida, USA) Phytoplankton to Nitrogen, Phosphorus, and Everglades Agricultural Area Canal Water. Lake and Reservoir Management, 13, 26-37. https://doi.org/10.1080/07438149709354293

Havens, K. E., \& Thomas, J. R. (2005). The phosphorus mass balance of Lake Okeechobee, Florida: Implications for eutrophication management. Lake and Reservoir Management, 21, 139-148. https://doi.org/10.1080/07438140509354423

Hedley, M. J., White, R. E., \& Nye, P. H. (1982). Plant-induced changes in the rhizosphere of rape (Brassica napus var. emerald) seedlings. III. Changes in $L$ value, soil phosphate fractions and phosphatase activity. New Phytologist, 91, 45-56. Retrieved from https://www.jstor.org/stable/2434349

HorsePropNet. (2020). Florida. Horse Properties Network. Retrieved from https://www.horseproperties.net/state/Florida

Horta, M. do-C., \& Torrent, J. (2007). The Olsen P test as an agronomic and environmental test for predicting phosphate release from acid soils. Nutrient Cycling in Agroecosystems, 77, 283-292. 
https://doi.org/10.1007/s10705-006-9066-2

Jankowiak J., Hattenrath-Lehmann, T., Kramer, B. J., Ladds, M., \& Gobler, C. J. (2019). Deciphering the effects of nitrogen, phosphorus, and temperature on cyanobacterial bloom intensification, diversity, and toxicity in western Lake Erie. Limnology and Oceanography, 64, 1347-1370. https://doi.org/10.1002/lno.11120

Komiyama, T., Ito, T., \& Saigusa, M. (2014). Measurement of the maximum amount of water-extractable phosphorus in animal manure compost by continuous and sequential water extraction. Soil Science and Plant. Nutrition, 60, 196-207. https://doi.org/10.1080/00380768.2013.879836

Krogman, U., Westendorf, M. L., \& Rogers, B. F. (2006). Best management practices for horse manure composting on small farms. Rutgers University, New Jersey. Retrieved from https://esc.rutgers.edu/fact_sheet/bestmanagement-practices-for-horses

Lankoski, J., \& Ollikainen, M. (2013). Innovations in Nonpoint Source Pollution Policy-European Perspectives. Choices (AAEA), 28(3). https://doi.orh/10.22004/ag.econ.159206

Lapointe, B. E., Herren, L. W., \& Paule, A. E. (2017). Septic systems contribute to nutrient pollution and harmful algal blooms in the St. Lucie Estuary, Southeast Florida, USA. Harmful Algae, 70, 1-22.

Lavin, T. E., Nielsen, B. D., Zingsheim, J. N., O'Connor-Robison, C. I., Link, J. E., Hill, G. M., \& Shelton, J. (2013). Effects of phytase supplementation in mature horses fed alfalfa hay and pelleted concentrate diets. Journal of Animal Science, 91, 1719-1727.

Levy, S. (2017). Microcystis rising: Why phosphorus reduction isn't enough to stop CyanoHABs. Environmental Health Perspectives, 125, A34-A39.

Liu, J., Spargo, J. T., Kleinman, P. J. A., Meinen, R., Moore Jr., P. A., \& Beegle, D. B. (2018). Water-extractable phosphorus in animal manure and manure compost: quantities, characteristics, and temporal changes. Journal of Environmental Quality, 47, 471-479. https://doi.org/10.2134/jeq2017.12.0467

Liu, Y., Guo, T., Wang, R., Engel, B. A., Flanagan, D. C., Li, S., Pijanowski, B. C., Collingsworth, P. D., Lee, J. G., \& Wallace, C. W. (2019). A SWAT-based optimization tool for obtaining cost-effective strategies for agricultural conservation practice implementation at watershed scales. Science of the Total Environment, 691, 685-696. https://doi.org/10.5194/hess-2019-232

Liu, Z., Choudhury, S. H., Xia, M., Holt, J., Wallen, C. M., Yuk, S., \& Sanborn, S. C. (2009). Water quality assessment of coastal Caloosahatchee River watershed, Florida. Journal of Environmental Science and Health, Part A: Toxic/Hazardous Substances \& Environmental Engineering, 44, 972-984. https://doi.org/10.1080/10934520902996872

Lou, H., Zhao, C., Yang, S., Shi, L., Wang, Y., Ren, X., \& Bai, J. (2018). Quantitative evaluation of legacy phosphorus and its spatial distribution. Journal of Environmental Management, 213, 296-305.

Louda, J. W., Duersch, B., Querioz, V., \& Cintron, C. (2019). Equestrian waste streams as a source of surfacewater phosphorus pollution. American Chemical Society $257^{\text {th }}$ Annual Meeting. Orlando, Florida. March 31April 4. Environmental.

Louda, J. W., Grant, C., Browne, J., \& Hagerthey, S. E. (2015). Pigment-based chemotaxonomy and its application to Everglades periphyton. In J. A. Entry, K. Jayachandrahan, A. D. Gottlieb, \& A. Ogram (Eds.), Microbiology of the Everglades Ecosystem (Chapter 13; pp. 287-347; plus appendices (pp.455-468) and color plate (p485).). Science Publishers.

Lu, J., Zhu, B., Struewing, I., Xu, N., \& Duan, S. (2019). Nitrogen-phosphorus associated metabolic activities during the development of a cyanobacterial bloom revealed by metatranscriptomics. Scientific Reports (Nature) 9, 2480. https://doi.org/10.1038/s41598-019-38481-2

Matsui, T., Murakami, Y., Yano, H., Fujikawa, H., Osawa, T., \& Asai Y. (1999). Phytate and phosphorus movements in the digestive tract of horses. Equine Veterinary Journal, Suppl., 30, 505-507. https://doi.org/10.1111/j.2042-3306.1999.tb05274.x

McCollum, R. E. (1991). Buildup and decline in soil phosphorus" 30 year trends on a typical umprabuult. Agronomy Journal, 83(3), 77-85. https://doi.org/10.2134/agronj1991.00021962008300010019x

McCollum, S. H., Cruz, O. E., Stem, L. T., Witttstruck, W. H., Ford, R. D., \& Watts, F. C. (1978). Soil Survey of Palm beach County Area, Florida. National Cooperative Soil Survey: United States Department of Agriculture and University of $\quad$ Florida. $104 \quad$ pp. Retrieved from https://www.nrcs.usda.gov/Internet/FSE_MANUSCRIPTS/florida/FL611/0/Palm_Beach.pdf 
McDowell, R. W., \& Stewart, I. (2006). The phosphorus composition of contrasting soils in pastoral, native and forest management in Otago, New Zealand: Sequential extraction and 31P NMR. Geoderma, 130(1-2), 176189. https://doi.org/0.1016/j.geoderma.2005.01.020

McDowell, R., Dodd, R., Pletnyakov, P., \& Noble, A. (2020). The ability to reduce soil legacy phosphorus at a country scale. Frontiers in Environmental Science, 8, Article 6 (12pp.) https://doi.org/10.3389/fenvs.2020.00006

Meals, D. W., Davenport, T. E., \& Dressing, S. A. (2010). Lag time in water quality response to best management practices: A Review. Journal of Environmental Quality, 39, 85-96. https://doi.org/10.2134/jeq2009.0108

Meeroff, D. E., Bloestscher, F., Long, S. C., \& Bocca, T. (2014). The use of multiple tracers to evaluate the impact of sewered and non-sewered development on coast water quality in a rural area of Florida. Water Environment Research, 86, 445-456. 10.2175/106143013x13807328848135

Morse, H. (2020). West Palm horse poop, wood shavings recycling plant gets county approval. The Palm Beach Post. Retrieved from https://www.palmbeachpost.com/story/news/local/2020/11/24/ equestrian-waste-canrecycled-suburban-west-palm-beach-facility/6405458002/

Motavalli, P. P., \& Miles, R. J. (2002). Soil phosphorus fractions after 111 years of animal manure and fertilizer

applications. Biology and Fertility of Soils, 36, 35-42. https://doi.org/10.1007/s00374-002-0500-6

Mullins, G., Jouern, B., \& Sharpley, A. N. (2005). By-Product phosphorus: Sources, characteristics, and management. Chpt. 26. In T. J. Sims, \& A. N. Sharpley (Eds.), Phosphorus: Agriculture and the Environment. Agronomy Monographs (Vol. 46). American Society of Agronomy, Crop Science Society of America, and Soil Science Society of America. https://doi.org/10.2134/agronmonogr46.c26

Naravanen, A., Jansson, H., Usi-Kamppa, J., Jansson, H., \& Prala, P. (2008). Phosphorus load from equine critical source areas and its reduction using ferric sulphate. Boreal Environment Research, 13, 265-274. Retrieved from https://orgprints.org/16436/1/ber.pdf

Negassa, W., \& Leinweber, P. (2009). How does the Hedley sequential phosphorus fractionation reflect impacts of land use and management on soil phosphorus: a review. Journal of Plant Nutrition and Soil Science, 172(3), 305-325.

Neitsch, S. L., Arnold, J. G., Kiniry, J. R., \& Williams, J. R. (2011). Soil and Water Assessment Tool Theoretical Documentation Version 2009; Texas Water Resources Institute: College Station, TX, USA, pp. 1-618. Retrieved from https://swat.tamu.edu/media/99192/swat2009-theory.pdf

NOLA. (2020). https://www.nola.com/entertainment_life/home_garden/article_987597b0-ef2d-56a2-9def$434 \mathrm{c} 27541 \mathrm{~d} 94 . \mathrm{html}$

Oklahoma State. (2017). https://extension.okstate.edu/fact-sheets/minerals-for-horses-calcium-andphosphorus.html

Olsen, S., Cole, C., Watanabe, F., \& Dean, L. (1954). Estimation of available phosphorus in soils by extraction with sodium bicarbonate. USDA Circular Nr. 939, US Gov. Print. Office, Washington, D.C. Retrieved from http://www.sciepub.com/reference/127419

Osetek, J., \& Louda, J. W. (2004). Water quality analyses of canals in the agricultural / residential community of Loxahatchee Groves, Florida. $68^{\text {th }}$. Annual Meeting of the Florida Academy of Sciences. Orlando, Fl., March 12-13, 2004. Abstract ENV-10.

Pavinato, P. S., Chrubin, M. R., Soltangheisi, A., Rocha, G. C., Chadwick, D. R., \& Jones, D. L. (2020). Revealing soil legacy phosphorus to promote sustainable agriculture in Brazil. Scientific Reports (Nature), 10, 15615. https://doi.org/10.1038/s41598-020-72302-1

Paerl, H. W. (1988). Nuisance phytoplankton and inland waters' blooms in coastal, estuaries. Limnology and Oceanography, 33, 823-847. https://doi.org/10.4319/1o.1988.33.4part2.0823

Paerl, H. W. (2008) Nutrient and other environmental controls of harmful cyanobacterial blooms along the freshwater-marine continuum. In Hudnell, H. K. (Ed.), Proceedings of the Interagency, International Symposium on Cyanobacteria Harmful Algal Blooms (Chapter 10; pp. 215-241). Retrieved from https://www.springer.com/gp/book/9780387758640

Paerl, H. W., Scott, J. T., McCarthy, M. J., Newell, S. E., Gardner, W. S., Havens, K. E., Hoffman, D. K., Wilhem, S. W., \& Wurtsbaugh, W. A. (2016). It Takes Two to Tango: When and Where Dual Nutrient (N \& P) 
Reductions Are Needed to Protect Lakes and Downstream Ecosystems. Environmental Science and Technology, 50(20), 10805-10813. https://doi.org/10.1021/acs.est.6b02575

Paerl, H. W., Xu, H., McCarthy, M. J., Zhu, G., Qin, B., Li, Y., \& Gardner, W. S. (2011). Controlling harmful cyanobacterial blooms in a hyper-eutrophic lake (Lake Taihu, China): The need for a dual nutrient (N \& P) management strategy. Water Research, 45, 1973-1983.

Pagliari, P. H., \& Laboski, C. A. M. (2012). Investigation of the inorganic and organic phosphorus forms in animal manure. Journal of Environmental Quality, 41, 901-910. https://doi.org/10.2134/jeq2011.0451

Pant, H. K., \& Reddy, K. R. (2001). Phosphorus sorption characteristics of estuarine sediments under different redox conditions. Journal of Environmental Quality, 30, 1474-1480. https://doi.org/10.2134/jeq2001.3041474x

Parvage, M. M., Ulen, B., \& Kirchmann, H. (2013). A survey of soil phosphorus (P) and nitrogen (N) in Swedish horse paddocks. Agriculture, Ecosystems, and Environment, 178, 1-9. https://doi.org/10.1007/s00374-0120746-6

PBPost. (2019). As Wellington equestrian community grows, so does the season, new report shows. K. Webb. Palm Beach Post. Sept.15, p. 1B. Retrieved from www.pbpost.com

Phlips, E. J., Badylak, S., \& Grosskopf, T. (2002). Factors affecting the abundance of phytoplankton in a restricted subtropical lagoon, the Indian River Lagoon, Florida, USA. Estuarine, Coastal and Shelf Science, 55, 385402.

Pierce, J. J., Weiner, R. F., \& Vesilind, P. A. (1998). Nonpoint source water pollution. Environ. Pollut. Control $4^{\text {th }}$. Edition, Chpt. 10: 137-143.

Pollman, C. D., \& Thomas, J. R. (2011). A simple model of internal loading of phosphorus in Lake Okeechobee. Lake and Reservoir Management, 27, 15-27. https://doi.org/10.1080/07438141.2010.542877

Reddy, K. R., Newman, S., Osborne, T. Z., White, J. R., \& Fitz, H. C. (2011). Phosphorus cycling in the Greater Everglades Ecosystem: Legacy phosphorus implications for management and restoration. Critical Reviews in Environmental Science and Technology, 41, 149-186. https://doi.org/10.1080/10643389.2010.530932

Reddy, K. R., Wang, Y., DeBusk, W. F., Fisher, M. M., \& Newman, S. (1998). Forms of Soil Phosphorus in Selected Hydrologic Units of the Florida Everglades. Soil Science Society of America Journal, 62(4), 1134-1147 https://doi.org/10.2136/sssaj1998.03615995006200040039x

Redfield, A. C. (1934). On the proportions of organic derivatives in sea water and their relation to the composition of plankton. Liverpool: James Johnstone Memorial Volume. pp 176-92. Retrieved from https://www.worldcat.org/title/james-johnstone-memorial-volume/oclc/13993674

Redfield, A. C. (1958). The biological control of chemical factors in the environment. American Scientist, 46, 20521. Retrieved from www.jstor.org/stable/27827150

Ris, C. (2007). U.S. EPA Health Assessment for Diesel Engine Exhaust: A Review. Inhalation Toxicology, 19, 229239.

Ruttenberg, K. C. (2014). Sedimentary organic phosphorus: composition and reactivity. In H. D. Holland, \& K. K. Turekian (Eds.), Treatise on Geochemistry (2nd Ed., Vol. 10; pp. 499-558). Elsevier. https://doi.org/10.1016/B978-0-08-095975-7.00813-5

Salvi, S., Blomberg, A., Rudell, B., Kelly, F., Sandstrom, T., Holgate S. T., \& Frew, A. (1999). Acute inflammatory responses in the airways and peripheral blood after short-term exposure to diesel exhaust in healthy human volunteers. American Journal of Respiratory Care and Medicine, 159, 702-709. https://doi.org/10.1164/ajrccm.159.3.9709083

Schlesinger, W. H., \& Bernhardt, E. S. (2013). The Global Cycles of Nitrogen and Phosphorus. In Schlesinger, W. H., \& Bernhardt, E. S. (Eds.), Biogeochemistry (3rd ed., pp. 445-467). Academic Press.

Sharp, J. H. (2002). Historical Perspective and the analytical problem. In D. A. Hansell, \& C. A. Carlson (Eds.), Biogeochemistry of Marine Dissolved Organic Matter (pp. 35-58). Academic Press.

Sharpley, A., Jarvie, H. P., Buda, A., May, L., Spears, B., \& Kleinman, P. (2013). Phosphorus Legacy: Overcoming the Effects of Past Management Practices to Mitigate Future Water Quality Impairment. Journal of Environmental Quality, 42(5), 1308-1326. https://doi.org/10.2134/jeq2013.03.0098

Shen, Z., Zhong, Y., Huang, Q., \& Chen, L. (2015). Identifying non-point source priority management areas in 
watersheds with multiple functional zones. Water Research, 68, 563-571.

Shtangeeva, I., Laiho, J. V.-P., Kahelin, H., \& Gobran, G. R. (2004). Improvement of phytoremediation effects with help of different fertilizers. Soil Science and Plant Nutrition, 50, 885-889. https://doi.org/10.1080/00380768.2004.10408550

Sims, J. T., Edwards, A. C., Schoumans, O. F., \& Simard, R. R. (2000). Integrating soil phosphorus testing into environmentally based agricultural management practices. Journal of Environmental Quality, 29, 60-71. https://doi.org/10.2134/jeq2000.00472425002900010008x

Skoglund, E., Carlsson, N.-G., \& Sandberg, A. S. (2009). Phytate. In P. R. Shewry, \& J. L. Ward (Eds.), Health Grain methods: Analysis of bioactive components in small grain cereals (pp.129-139). AACC International, Elsevier.

Smith, V. H., Tilman, G. D., \& Nekola, J. C. (1999). Eutrophication: impacts of excess nutrient inputs on freshwater, marine, and terrestrial ecosystems. Environmental Pollution, 100, 179-196. https://doi.org/10.1016/S02697491(99)00091-3

Stuck, J. D., Izuno, F. T., Campbell, K. L., Bottcher, A. B., \& Rice, R. W. (2001). Farm-level studies of particulate phosphorus transport in the Everglades Agricultural Area. Transactions ASAE, 44, 1105-1116. https://doi.org/10.13031/2013.6438

Tadesse, S. T., Oenema, O., van Beek, C., \& Ocho, F. L. (2020). Manure recycling from urban livestock farms for closing the urban0rural nutrient loops. Nutrient Cycling in Agroecosystems, 119, 51-67.

Tuo, Y., Chiogna, G., \& Disse, M. (2015). A Multi-Criteria Model Selection Protocol for Practical Applications to Nutrient Transport at the Catchment Scale. Water, 7, 2851-2880. https://doi.org/10.3390/w7062851

Turner, B. L., \& Leytem, A. B. (2004). Phosphorus compounds in sequential extracts of animal manures: Chemical speciation and a novel fractionation procedure. Environmental Science and Technology, 38(22), 6101-6108. https://doi.org/10.1021/es0493042

UMinn. (2020). University of Minnesota Extension. Retrieved from https://extension.umn.edu/horse-care-andmanagement/managing-and-composting-horse-manure

US-DOE. (2015). 2014 Vehicle Technologies Market Report. Office of Energy Efficiency \& Renewable Energy, United States Department of Energy. 194pp. Retrieved from https://tedb.ornl.gov/wp-content/uploads/ 2019/04/2014_Vehicle_Technologies_Market_Report.pdf

USEPA. (2005). Handbook for developing watershed plans to restore and protect our waters. EPA-841-B-05-005. U.S. Environmental Protection Agency, Office of Water, Washington, DC. Retrieved from https://www.epa.gov/sites/production/files/2015-09/documents/2008_04_18_nps_watershed_ handbook_handbook-2.pdf

USEPA. (2011). U.S. Environmental Protection Agency (EPA), Washington, D.C. "EPA Administered Permit Programs: The National Pollutant Discharge Elimination System." Code of Federal Regulations, 40 C.F.R. 122.2 Retrieved from https://www.govinfo.gov/content/pkg/CFR-2011-title40-vol22/pdf/CFR-2011-title40 vol22-part122.pdf

USEPA. (2016). National Nonpoint Source Program - a catalyst for water quality improvements. U.S. Environmental Protection Agency (EPA), Washington, D.C. EPA 841-R-16-009.

USEPA. (2019). Clean Water Act Section 502: General Definitions. Retrieved from https://www.epa.gov/cwa404/clean-water-act-section-502-general-definitions

Vadas, P. A., Harmel, R. D., \& Kleinman, P. J. A. (2007). Transformations of soil and manure phosphorus after surface application of manure to field plots. Nutrient Cycling in Agroecosystems, 77, 83-99.

VTech. (2006). https://www.sites.ext.vt.edu/newsletter-archive/dairy/2006-07/phosphorus.html

Webb, K. (2019). As Wellington equestrian community grows, so does the season, new report shows. The Palm Beach Post. Sept. 15, p. 1B. Retrieved from www.palmbeachpost.com

WER. (2020). Wellington Horse Shows. Wellington Equestrian Realty. Retrieved from https://wellingtonequestrianrealty.com/wellington-horse-shows

Xie, Z., Fong, W.-P., \& Tsang, P.W.-K. (2020). Engineering and optimization of phosphate-responsive phytase expression in Pichia pastoris yeast for phytate hydrolysis. Enzyme and Microbial Technology, 137, 109533. https://doi.org/10.1016/j.enzmictec.2020.109533 
Zhang, N.-M., Yang, Y., Bo, H., Chen, J.-J., \& Zhang, Y.-J. (2004). Factors influencing runoff P losses from farmlands of the Dianchi Lake Watershed in Yunnan, China. Pedosphere, 14(2), 259-262.

Zhu, Z., Broersma, K., \& Mazumder, A. (2012). Impacts of land use, fertilizer and manure application on the stream nutrient loadings in the Salmon River watershed, South-Central British Columbia, Canada. Journal of Environ. Protection, 3, 809-822. https://doi.org/10.4236/jep.2012.328096

\section{Copyrights}

Copyright for this article is retained by the author(s), with first publication rights granted to the journal.

This is an open-access article distributed under the terms and conditions of the Creative Commons Attribution license (http://creativecommons.org/licenses/by/4.0/). 